\title{
Ana Buriano Castro
}

Profesora investigadora titular, Instituto Mora. Doctora en Estudios Latinoamericanos. Investigadora nacional. Su principal línea de investigación está centrada en el análisis del pensamiento político latinoamericano, con especialidad en el pensamiento conservador ecuatoriano. Entre sus publicaciones recientes: El "espíritu nacional" del Ecuador católico: artículos selectos de El Nacional, 1872-1875, Instituto Mora, México, 2011; "La construcción historiográfica de la nación ecuatoriana en los textos tempranos" en Guillermo Palacios (coord.), La nación y su bistoria: América Latina, siglo XIX, Colmex, México, 2009; Navegando en la borrasca: construir la nación de la fe en el mundo de la impiedad. Ecuador, 1860-1875, Instituto Mora, México, 2008; "Ecuador latitud 0: una mirada al proceso de construcción de la nación" en J. C. Chiaramonte, Carlos Marichal y Aimé Granados (coords.), Las nombres de los países de América Latina: identidades políticas y nacionalismo, Sudamericana, Buenos Aires, 2008; coautora de "En las redes del agio y la diplomacia: Francisco de Paula Pastor, representante de Ecuador en México, 1832-1864”, Revista Mexicana de Política Exterior, núm. 88, febrero de 2010.

\section{Resumen}

Estudio de una coyuntura postergada y reducida a la condición de Interregno (1865-1868) entre las dos administraciones de García Moreno. Apoyado en fuentes legislativas, hemerográficas, epistolario y follerería, el artículo profundiza en el año de mayor potencial del trienio como un momento privilegiado para la observación de las prácticas políticas. 1868 condensa la emergencia de varias novedades. Entre ellas la de un proyecto alternativo sustentado en una alianza interregional que esbozó un agrupamiento político civilista y tercerista que trascendería. Fue también pródigo en conflictos con las gubernaturas provinciales y cuna de una eclosión editorial reflejo de la libertad de imprenta. Un nuevo Ecuador católico, moderno, tolerante, fincado en bases civilistas parecía emerger y barrer el proyecto centralista y autoritario. La campaña electoral de 1868 activó el campo de la política en la disputa por el gobierno.

Palabras clave:

Ecuador, coyuntura electoral, conservadores, progresistas, liberales, prácticas políticas.

Fecha de recepción: octubre de 2011
Fecha de aceptación:

marzo de 2012 


\title{
Ecuador 1868: the Frustration of a Transition. Electoral Situation and Political Practices
}

\author{
Ana Buriano Castro
}

Tenured Research Ptofessor, Instituto Mora. Ph. D. in Latin American Studies. National Researcher. Her main line of research focuses on the analysis of Latin American political thought, specializing in conservative Ecuadorean thought. Recent publications include: El "espiritu nacional" del Ecuador católico: artículos selectos de El Nacional, 1872-1875, Instituto Mora, México, 2011; "La construcción historiográfica de la nación ecuatoriana en los textos tempranos" in Guillermo Palacios (coord.), La nación y su bistoria: América Latina, siglo XIX. Colmex, México, 2009; Navegando en la borrasca: construir la nación de la fe en el mundo de la impiedad. Ecuador, 1860-1875, Instituto Mora, México, 2008; "Ecuador latitud 0: una mirada al proceso de construcción de la nación" in J. C. Chiaramonte, Carlos Marichal and Aimé Granados (coords.), Los nombres de los países de América Latina: identidades politicas y nacionalismo, Sudamericana, Buenos Aires, 2008; "En las redes del agio y la diplomacia: Francisco de Paula Pastor, representante de Ecuador en México, 1832-1864", Revista Mexicana de Política Exterior, no. 88, February, 2010 (coaut.).

\begin{abstract}
Study of a situation that was postponed and reduced to the condition of Inter-regnum (1865-1868) between the two administrations of García Moreno. Based on legislative and newspaper sources, letters and leaflets, the article focuses on the year with the greatest potential in the triennial period as a critical moment for the observation of political practices. 1868 condenses the emergence of vatious novelties. These include an alternative project based on

nental, third party political group that would transcend. It was also a period of numerous conflicts with provincial governorships and the cradle of an editorial eclosion that reflected the freedom of the printing press. A new Catholic, modern, tolerant Ecuador, with continental bases, seemed to be emerging and sweeping away the centralist, authoritarian project. The electoral campaign of 1868 activated the field of politics in the dispute over government.
\end{abstract} an inter-regional alliance that outlined a conti-

Key words:

Ecuador, electoral period, conservatives, progressives, liberals, political practices. 


\title{
Ecuador 1868: la frustración de una transición. Coyuntura electoral y prácticas políticas
}

\author{
Ana Buriano Castro
}

\section{INTRODUCCIÓN}

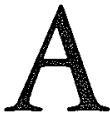

I finalizar su periodo constitucional, en 1865, Gabriel García Mo-

reno propuso como sucesor al rico cacaotero guayaquileño José María Caamaño. Veía en él al continuador del proyecto modernizador que había esbozado durante su primera administración, al tiempo que introducía un costero capaz de controlar una región vital del país que le había sido particularmente hostil. Pronto comprendió que no era el hombre adecuado. Cuando clausuró la Sociedad Republicana de Quito por oponérsele y promover la candidatura de Manuel Gómez de la Torre, Caamaño renunció por ética a la postulación. ${ }^{1}$ En palabras de García, cometió una "sandez supina", ${ }^{2}$ declaración poco afortunada con la que logró sumar un enemigo más al incipiente círculo opositor que se desgajaba del inicial consenso de elites que lo rodeó duran-

1 Véase, Caamaño, "Exposición", 1966, vol. 3 , pp. 291-292. Caamaño expresó que las sociedades formadas para apoyar a Gómez de la Torre no eran "clubs sediciosos" como afirmaba García, sino agrupamientos con fines "puramente políticos, destinados a trabajar por vías legales a favor de una candidatura."

${ }^{2}$ García a Sarrade, Quito, 1 de marzo de 1865 en Loor, Cartas, 1966, vol. 3, p. 289. te su primera presidencia (1861-1865). En las elecciones de 1865 , calificadas como "una farsa" digitada por el ejecutivo, ${ }^{3}$ el caudillo propuso un nuevo candidato, el lojano Jerónimo Carrión, comprometido con la modernización católica. ${ }^{4}$ No logró un apoyo unánime a la candidatura, ni el mismo García estaba convencido de la fidelidad que le guardaría. ${ }^{5}$

Si bien es cierto que el cuatrienio denominado Interregno, periodo entre la primera y la segunda administraciones garcianas, supuso una continuidad de los proyectos iniciados entre 1861 y 1865 -escuelas, obras públicas y alianza Iglesia-

${ }^{3}$ Borrero, Refutación, 1957-1968, vol. 2, pp. 74-87. Da cuenta de las presiones que se ejercieron durante el proceso. Hubo prisión para quienes imprimieran propaganda favorable a Gómez de la Torre, se removió al gobernador interino de Cuenca Antonio Mansilla junto con algunos jefes políticos que no se alinearon con la candidatura oficial, se intentó detener al grupo opositor de políticos cuencanos y se clausuraron sus periódicos, entre otras denuncias.

${ }^{4}$ García a Borrero, Quito, 16 de marzo de 1864 en Loor, Cartas, 1966, vol. 3, pp. 204-205.

${ }^{5}$ García Moreno a Antonio Borrero, Guayaquil, 23 de abril de 1864 en ibid., pp. 211-212. Le comunicaba su desconfranza: "Estoy convencido que si el señor Carrión sale de presidente u otro cualquiera del interior, la restauración de los malvados urbinistas es pronta e inevitable." 
Estado consagrada en un concordato promulgado en 1866-, ${ }^{6}$ algo nuevo flotaba en el aire. La llegada de Carrión al gobierno supuso una apertura y un tono diferente del que privó en la administración garciana, signada por sangrientos episodios. ${ }^{7}$ Juan Montalvo comenzó a publicar El Cosmopolita en enero de 1866; la libertad de prensa permitió que las imprentas sacaran a la luz folletos de crítica al gobiernể anterior, así como las réplicas de sus defensores. ${ }^{8}$ Las amnistías beneficiaron a los exiliados; Manuel Bustamante, suegro de Carrión y encarnizado enemigo de García Moreno, ${ }^{9}$ llegó al Ministerio del Interior y Relaciones Exteriores y en el Congreso del año los liberales obtuvieron la mayoría. Aunque el gobierno buscaba recomponer y prescindir de la represión el ministro Bustamante era confrontativo e intentaba un corte radical con su predecesor. Pagaría un alto costo por esta osadía y Carrión debería renunciar al cargo en noviembre de 1867, a mitad de su periodo.

Así llegó Javier Espinosa a la presidencia para cubrir el tramo restante. Tam-

${ }^{6}$ Henderson, Gabriel, 2008.

${ }^{7}$ Nos referimos a los fusilamientos posteriores a la derrota de la invasión de Urbina en Jambelí, al ajusticiamiento del general Tomás Maldonado y a otros actos represivos.

${ }^{8}$ Zaldumbide, "Congreso", 1865; Unos quiteños, "Señor", 1865, posiblemente de la pluma del propio García Moreno, quien respondía a las críticas de Montalvo en El Cosmopolita con unos sonetos satíricos: "A Juan" y "Soneto". Robalino, Orígenes, 1948, pp. 308-309.

${ }^{9} \mathrm{La}$ enemistad entre ambos personajes tenía larga data desde que, en 1848 bajo el gobierno de Roca, García Moreno abofeteó y retó a duelo a Bustamante. El juicio subsiguiente lo obligó a esconderse en la costa y partir exiliado a Europa. Robalino, Origenes, 1948, pp. 57-62. bién fue un candidato a modo de García Moreno. Sin embargo, su actuación demostró que el cambio en el estilo de hacer política que había dejado entrever el gobierno de Carrión no respondía a la circunstancia fortuita de su personalidad ni la de su primer ministro. Parecía más bien una necesidad de las elites: un intento quizá de retrotraer el debate político a los modos del periodo pregarciano. Espinosa buscó desesperadamente el centro y apostó al apego a la legalidad para construir su legitimidad. Tampoco logró recomponer ni moderar el debate porque, desde 1865 , las tendencias habían logrado otro grado de definición.

El artículo busca el "tiempo de la política" 10 y lo encuentra en la coyuntura electoral que inicia en 1868, durante la administración de Espinosa. El año condensa la emergencia de varias novedades. Entre ellas un proyecto alternativo sustentado en una alianza interregional que dio origen a un agrupamiento político civilista y tercerista que alcanzaría trascendencia posterior. Vio también poner en operación un banco emisor que preludiaba una recomposición de las elites guayaquileñas. Fue también pródigo en conflictos con las gubernaturas provinciales y continuación de la eclosión editorial iniciada en el primer año del Interregno. Un nuevo Ecuador parecía emerger, una especie de tránsito se esbozaba y prometía barrer el proyecto centralista. Se alzaba la promesa de un país católico y modernizante fincado en bases más civilistas y menos represivas. Con el gobierno en disputa en medio de una intensa lucha electoral, el año se convierte en un momento pri-

${ }^{10}$ Palti, Tiempo, 2007. El campo concreto de la disputa por el poder. 
vilegiado para observar la política y sus prácticas.

A partir de epistolarios, folletos y hemerografía el artículo se aproxima al estudio del año de mayor potencial del cuatrieñio. Se trata de una coyuntura historiográficamente postergada y comprimida entre los dos tramos de los gobiernos de García Moreno. No puede decirse propiamente que no ha tenido consideración en los grandes estudios sobre el garcianismo, sin embargo su significación se ha visto aminorada no sólo por su condición de interludio sino por la omnipresencia de García ganando la escena. El periodo tuvo una consideración en la literatura política de la época y en los tratamientos ensayísticos e historiog ráficos cuencanos. Estos estudios privilegiaron el análisis del "liberalismo católico" azuayo ${ }^{11}$ en función de la actuación destacada de esta corriente en el periodo. Antonio Borrero, en su Refutación a la obra del padre Berthe, le dedicó un amplio tratamiento que constituye una fuente insoslayable. ${ }^{12}$ Jijón y Caamaño lo considera en su Politica conservadora. ${ }^{13} \mathrm{La}$ historia del padre Le Gouhir $^{14}$ y la del padre Berthe ${ }^{15}$ le prestan consideración y todas las grandes biografías clásicas sobre García Moreno contienen datos imprescindibles para el conocimiento del periodo. Lo mismo ocurre con los estudios regionales sobre el Azuay y sus personalidades destacadas.

1. Azuayo gentilicio de la provincia del Azuay que obtiene su nombre del nudo montañoso de la sierra sur de Ecuador. Tiene su capital en Cuenca y comprende a Loja.

12 Borrero, Refutación, 1957-1968, vol. 2.

${ }^{13}$ Jijón, Política, s. a.

${ }^{14}$ Gouhir, Gran, 1923.

${ }^{15}$ Berthe, Ganiá, 1892
Recientemente la corriente "progresista" ha sido abordada desde la Universidad de Cuenca por María Cristina Cárdenas Reyes en obras ampliamente documentadas. ${ }^{16}$

La aparición de un proyecto alternativo en Cuenca es una de las novedades más atractivas del momento político. Pero no es el centro de este tratamiento. Tampoco lo es García Moreno, aunque resulte imposible deshacerse de él. El artículo busca la dinámica política en la forma de manejar la lucha por el poder, en el uso de las influencias y las redes de amistad que se configuran y reconfiguran en la coyuntura electoral. Nos preocupa observar cómo se fabrican las candidaturas, cómo se coquetea con el poder, cómo se manipulan los procesos electorales, cómo se mueven los hombres entre las tendencias y aun dentro de una misma; las formas que utilizan para ganar legitimidad o para prescindir de ella. Un solo año es quizá un tiempo demasiado breve para obtener conclusiones definitivas en torno a estas manifestaciones de las culturas políticas del XIX ecuatoriano. Los objetivos y las fuentes manejadas impiden abarcar a profundidad el conjunto de problemas que ocupan a la nueva historia política: el ancho campo de estudios relativos a la formación de la ciudadanía, la participación, el asociacionismo, la representación y las reformas electorales. ${ }^{17}$ Este estudio no es más que la instantánea de un momento. Y si bien ese momento es una coyuntura electoral, la mirada no sobrepasa el ámbito

${ }^{16}$ Cárdenas, Región, 2005.

${ }^{17}$ Para un análisis de los cambios constitucionales efectuados durante el periodo garciano en la representación y la ampliación de la ciudadanía véase Henderson, "Constitución", 2009, pp. 47-67, y Buriano, "Constitucionalismo," 2004, pp. 64-94. 
de las prácticas y el instante concreto del estado de la opinión pública, el horizonte que alcanzamos desde el punto de observación en que estamos situados. El artículo revalora también la historia de la presidencia de Javier Espinosa, una figura historiográficamente disminuida. Los garcianos insistieron tanto en su debilidad que los historiadores terminaron por creerles. Proponemos en cambio que Espinosa fue un decidido impulsor del sentido, quizá mayoritario, que las elites deseaban imprimir al país. Sin embargo, la encrucijada era adversa a este y otros propósitos.

\section{7: UN AÑO DIFÍCIL}

Las elecciones de 1865 , las primeras presidenciales que se hacían con un sistema electoral de plena elección popular y con un electorado relativamente extendido, ${ }^{18}$ evidenciaron un clima diferente. El enfrentamiento entre los "gomistas", es decir los partidarios de Gómez de la Torre, y los "garcistas" promotores de los sucesivos candidatos garcianos (CaamañoCarrión), había activado los ánimos al grado de que se conformaton clubes, que no eran partidos sino agrupamientos de connotación electoral. ${ }^{19}$ Se enfrentaban "el partido del orden y la religión" y los "rojos", en el lenguaje de los conservadores. El club Republicano de Quito asignó

${ }^{18}$ A partir de las modificaciones plasmadas en la Constitución de 1861 todos los cargos eran de elección popular y se habían eliminado los requisitos censatatios.

${ }^{19}$ En Quito el clausurado Club Republicano promovió a Gómez de la Torre y la Sociedad Conservadora, además de homenajear al presidente saliente, asumió la promoción de sus candidatos. el mote de "terroristas" a los partidarios de García.

Instalado el nuevo gobierno, el "Gran Elector" ${ }^{20}$ en el que se había convertido García Moreno manifestó muy pronto discrepancias con la política del presidente. ${ }^{21}$ Existió, sin embargo, un cierto impasse inicial motivado tanto por las circunstancias personales del caudillo ${ }^{22}$ como por el hecho de haber aceptado fugazmente el cargo de encargado de Negocios y ministro plenipotenciarios de Ecuador en Chile. Pese a ello, 1867 se presentaba con otra fisonomía. Ecuador vivía los efectos de la guerra hispanoamericana en el Pacífico. Había abandonado la actitud de neutralidad del periodo anterior y se había plegado finalmente a la Unión Americana conformada por Perú, Chile y Bolivia. El alineamiento contra España, el principal comprador de la agroexportación cacaotera, llevó los precios del cacao a su mínima expresión. Ecuador fue así el país más afectado en lo económico de entre los involucrados en el conflicto. ${ }^{23}$ Carrión no influyó en las elecciones legislativas para el Congreso del año y los liberales se alzaron con una relativa mayoría, a tal punto que Pedro Carbo, el líder de los liberales moderados de Guayaquil, presidía el Senado. El general Secundino Darquea, in-

${ }^{20}$ Robalino, Orígenes, 1948, p. 312.

${ }^{21}$ Veinte días después de que Carrión asumiera, García criticaba los nombramientos que hacía el nuevo presidente, García a Barreiro, Quito, 27 de septiembre de 1865 en Loor, Cartas, 1966, vol. 3, p. 320.

${ }^{22}$ En noviembre de 1865 falleció la primera esposa de García Moreno y en abril de 1866 contrajo nupcias con su joven sobrina Mariana de Alcázar.

${ }^{23}$ Ello explicaría la actitud antiamericanista que adoptó García cuando declaró la neutralidad del país. No quiso arrostrar los daños económicos que sufrió Ecuador durante el Interregno. 
condicional soldado de García Moreno en la costa, fue acusado de fraguar la detención del presidente. ${ }^{24}$ Algunos gobernadores no comulgaban con la tendencia conservadora y García, que atendía los negocios de su hermano en Guayaquil, tenía la sensación de que el complot tomaba proporciones desmesuradas. ${ }^{25}$ Real o imaginada, esta sensación se reforzó cuando el Congreso lo rechazó como senador electo por la provincia de Pichincha y reconoció en su lugar a Manuel Angulo, que lo superaba ampliamente en votos. ${ }^{26} \mathrm{La}$ baja votación que obtuvo en la elección le permitía comprender que su popularidad se había desgastado en el ejercicio de la presidencia y que el pragmatismo de ciertas elites lo había convertido en un político prescindible, ahora que reinaba una relativa paz.

El gobierno de Carrión enfrentaba también muchos problemas. Entre ellos los desencuentros entre el Estado y la Iglesia. Durante la primera presidencia de García Moreno estos enfrentamientos habían tenido un agitado periplo que rese-

${ }^{24}$ Darquea indignado rechazó este cargo con una "Proclama al público", El Nacional, 25 de abril de 1866, en LC, Registro oficial, microfilme, $35 \mathrm{~mm}$, rollo 8 (en adelante El Nacional).

${ }^{25}$ García estaba convencido de que violaban y sustraían su correspondencia. Acusaba de ello al gobernador del Azuay, Miguel Heredia, hecho que el implicado negaba indignado. Véase García a Borja, Guayaquil, 29 de junio de 1867 y Heredia a García, Cuenca, 6 de julio de 1867 en Loor, Cartas, 1966 , vol. 3, pp. 353-354 y 363-364.

${ }^{26}$ El doctor Angulo obtuvo 1136 votos y García Moreno 442. Sus partidarios lo impusieron en la Junta Electoral de la provincia de Pichincha argumentando imposibilidades legales del primero para ejercer la senaduría. El Senado revió el caso y aceptó a Angulo. Ecuador, Cámara de Senadores, Acta, 1867. ñaba el dominico Pío David Galindo en un folleto publicado bajo el gobierno de Carrión, amparado en la libertad de imprenta recién establecida. ${ }^{27}$ Se trataba de una denuncia de la represión que don Gabriel había ejercido contra la Iglesia nacional para convertirla en herramienta dócil en apoyo de su proyecto de construcción del Estado nacional. La reforma de los regulares, piedra angular de la reforma religiosa, había quedado inconclusa ante la resistencia de la orden dominica. Además, el papado se había mostrado partidario de utilizar medios suaves y diferidos para reformar al clero y, en las modificaciones al concordato, García no logró implantar su aspiración de que la Santa Sede dejara el asunto en manos del Estado. Nuevos visitadores italianos arribaron al país a principios del Interregno decididos a impulsar la reforma de los regulares y su intromisión generó disgusto. Las jerarquías de la orden programaron instalar a los padres italianos en el Convento Máximo, situado en el centro de Quito, y recluir a algunos padres nacionales resistentes en un pequeño conventillo de las afueras de la capital. El superior Tomás Larco consultó la decisión con las autoridades religiosas, pero no lo hizo con el ministro Bustamante, que era íntimo amigo de los padres nacionales y síndico mayor de la cofradía del Rosario. La adhesión popular hacia los dominicos ecuatorianos y la desconfianza hacia los italianos provocó el estallido de un ruidoso motín el 25 de julio de $1867 .{ }^{28}$ Durante más de cuatro

${ }^{27}$ Galindo, Reforma, 1866.

${ }^{28}$ A las 10 de la mañana las campanas tocaron a rebato, el nuncio se encerró dentro del convento asediado por una multitud predominantemente femenina que lanzó vivas a los padres nacionales y mueras 
horas las campanas de Santo Domingo sacudieron la capital, pero las autoridades civiles dejaron actuar a los sectores populares. Ante los reclamos del nuncio, Bustamante le respondió en términos duros y descomedidos. La respuesta del ministro evidenciaba no sólo su cercanía y afinidad con los muy politizados y populares padres nacionales sino que la nueva administración estaba determinada a separar su imagen del reformista régimen anterior. Por supuesto que la reforma debió postergarse para mejores momentos. El motín sentó un nuevo punto de discrepancia con los garcianos y el conflicto con la nunciatura sumó otra desavenencia a las ya existentes.

Tampoco Carrión estableció buenas migas con los liberales que dominaban el Congreso. Fue el propio Carbo quien inició el enfrentamiento al exigir que se privara al ejecutivo de las facultades extraordinarias que se mantenían vigentes desde la invasión de Urbina en 1865. ${ }^{29}$ El ministro Bustamente reaccionó con violencia, trató de disolver el Congreso y detuvo a dos senadores. Como el legislativo intentó realizar un juicio político al presidente Carrión, Bustamante lo rodeó con tropas y trató de disolverlo. El gobernador de Pichincha, Manuel Tobar, se negó a promulgar el decreto y el Congreso se instaló en sesión permanente. ${ }^{30}$ Carrión debió

a los italianos. Los disturbios no se calmaron hasta que el pueblo se aseguró de que los nacionales permanecerían en Quito. En torno al motín véase Ponce, “25", 1867. Fue replicado por Verdad, 1867 atribuido al padre Francisco Alomía.

${ }^{29}$ Robalino, Orígenes, 1948, pp. 310-311.

30 "Oficio del presidente del Senado pidiendo que el gobierno ponga a disposición de la Cámara a los $\mathrm{HH}$ senadores retenidos por indicios de conspiración, sesión del 27 de octubre", en Alcance a El Nacional, núm. 298, Quito, 1 de octubre de 1867. En el sacrificar la cabeza de su polémico suegro e integrar su gabinete con notorios garcianos. ${ }^{31}$ No logró salvar su gobierno pues ni liberales ni conservadores lo apoyaban. Un mes después el gabinete renunció al unísono con el objetivo de provocar la caída del presidente. Este pasó el mando al vicepresidente Pedro José de Arteta. García Moreno había decidido que la permanencia de Carrión no garantizaba la continuidad del proyecto. ${ }^{32}$ El presidente interino convocó a elecciones que finalizaron el 21 de diciembre de ese mismo año. "El católico y virtuoso" Javier Espinosa, el candidato de García, concitó la adhesión unánime de todas las tendencias; según comentó en carta a Félix Luque: "fue aceptado con entusiasmo, aun por una parte de los rojos [...] Tenemos pues electo un inmejorable presidente." 3.3

\section{8: ENTRE LOS TERREMOTOS \\ DE LA NATURALEZA Y LA POLÍTICA}

Espinosa demostró ser un hombre impecable, un verdadero purista de la institucionalidad; un ilustrado abogado quiteño de prestigio que había ocupado distintos

mismo número oficio similar de la Cámara de Diputados. "Estracto [sic] del Acta 5 de noviembre por la mañana" en Alcance a El Nacional, núm. 303, Quito, 8 de noviembre de 1867.

31 Rafael Carvajal, condiscípulo y amigo de García Moreno sustituyó a Bustamante en el Ministerio del Interior, Camilo Ponce, Manuel de Ascásubi y Bernardo Dávalos ocuparon cargos en el gabinete.

32 García a Carrión, Guayaquil, 30 de octubre de 1867 y García a Toral, Quito, 12 de noviembre de 1867 en Loor, Cartas, 1966, vol. 3, pp. 383-386.

33 García a Luque, Guayaquil, 25 de diciembre de 1867 en ibid., p. 390. 
cargos públicos vinculados a la justicia y la diplomacia. Había sido ministro del Interior de José Ma. Urbina, aunque se negó a firmar el decreto de expulsión de los jesuitas recién extrañados de Colombia y renunció al cargo. Pese a sus vínculos con el liberalismo, este acto consagró su fama de católico sin mácula. ${ }^{34}$ Designó como ministro del Interior a su pariente Camilo Ponce. Aunque Ponce provenía del liberalismo, había sido cooptado por García Moreno al punto de ocupar un ministerio. Espinosa era un hombre de concordia. Integró su gabinete con algunos conspicuos garcianos, como el cuñado del caudillo, Manuel de Ascásubi, a Francisco Javier Salazar en el ministerio de Guerra y Marina, y en Hacienda a Julio Castro por delegación de otro insigne conservador, Elías Laso. La mayoría de los gobernadores provinciales eran conservadores, con excepción de los de Cuenca y Ambato, después de que se produjo la remoción del gobernador electo (vid. infra). ${ }^{35}$

Instalado el Congreso el 8 de enero de 1868, verificó el escrutinio de presidente de la República en la sesión del 13 del mismo mes y constató que los 15904 votos obtenidos por Espinosa le daban una mayoría inalcanzable frente a otras personalidades que obtuvieron sufragios dispersos. Fue así legalmente reconocido como presidente constitucional. ${ }^{36}$ En esa

${ }^{34}$ Su confesor era el padre Cruciani, uno de los visitadores italianos de la orden dominica. Ello lo ponía salvo de toda sospechosa conexión con los refractarios padres nacionales.

${ }^{35}$ Borrero, Refutación, 1957, vol. 2, p. 215.

${ }^{36}$ Con la sola impugnación de Luis Cordero quien objetó un vicio de forma en la elección, dado que el Consejo de Gobierno no había conocido la misma sesión Espinosa rindió el juramento, precedido de una alocución del presidente del Senado, Manuel Angulo, quien lo exhortó a permitir que regresaran a la patria muchos de sus hijos exiliados por el régimen anterior, "que se alimentan en regiones extrañas con el pan humedecido con las lágrimas del destierro". Lo convocó también a respetar los derechos del hombre. ${ }^{37}$ Espinosa respondió con un discurso cuidadoso, donde sostuvo los principios que regirían su presidencia. Habló así del "respeto inviolable a la Constitución", de proteger la religión y la moral, de fomentar la educación pública y la difusión de las luces, impulsar mejoras materiales, llamar al servicio a los hombres honrados y virtuosos, "no ligarse a un partido político desconociendo las pretensiones legítimas y los derechos de los otros", impartir una justicia imparcial, acatar el derecho electoral de los ciudadanos y garantizar la libre publicación de sus pensamientos. Prometió también ser inflexible en el castigo del crimen pero "rechazar con firmeza la insidiosa delación que degrada la dignidad del magistrado e infunde en los ciudadanos esas negras desconfranzas que... son el origen de las revueltas intestinas". Tuvo luego un gesto de apaciguamiento hacia su antecesor que no podía dejar de sentirse aludido por muchos de los preceptos que Espinosa enunciaba. Sin nombrarlo dijo que se serviría de las luces de los ciudadanos caracterizados que lo habían precedido, pero también afirmó que prestaría atención a cualquier ecuatoriano ilustrado y probo, al

renuncia de Carrión. "Acta del Congreso del 13 de enero", El Nacional, 25 de enero de 1868.

37 "Congreso extraordinario de 1868 " en $E l$ Nacional, 31 de enero de 1868. 
margen de sus opiniones políticas. ${ }^{38}$ No era un discurso simplemente continuista y muchos de sus enunciados deben haber sido campanadas de alerta para el grupo conservador, particularmente la mención a la legalidad electoral, la libertad de imprenta y la crítica al sistema de delación que había establecido García como forma de control. Espinosa seguiría la política de la primera administración en materia de religión, educación y progreso material del país, pero bajo postulados civilistas. Contra la idea generalizada de que era un hombre débil, debe reconocerse la valentía que emana del discurso, especialmente porque ya contaba en su experiencia la suerte corrida por su antecesor Carrión al intentar separarse de García Moreno. Había algo, sin embargo, que nublaba el horizonte del gobierno de Espinosa: el proceso electoral presidencial que debía verificarse durante su mandato, en mayo de 1869.

De las pocas actas que hemos logrado consultar $^{39}$ emana que el Congreso tuvo una corta duración. Instalado el 8 de enero finalizó sus sesiones el 31 de ese mes. Emitió algunos decretos legislativos relativos a la política exterior. Entre ellos, una acción de gracia celebratoria de la Unión Americana y de sus presidentes por "haber defendido el honor y los derechos de los pueblos americanos", en referencia al reciente conflicto con España. ${ }^{40}$ En el mis-

38 lbid.

39 La versión microfilmada de las Actas de este Congreso es ilegible para la Cámara de Senadores. En el microflim consta que las Actas de la Cámara de Diputados están perdidas. Sólo hemos consultado las pocas sesiones que transcribe El Nacional del año.

40 "El Senado y la Cámara de Diputados del Ecuador reunidos en Congreso", El Nacional, 25 de enero de 1868. mo tono americanista, del que Ecuador había sido ajeno hasta entonces, extendió una felicitación a la "Nación Mejicana [sic] por el triunfo que tan gloriosamente ha obtenido contra la dominación extraña". 41

La sesión del 11 de enero debió vérselas con la reñida elección del arzobispo de Quito vacante por la muerte del coadjutor. Los bandos se polarizaron en torno a los obispos de Ibarra y Riobamba, José Ignacio Checa y Barba y José Ignacio Ordóñez. Checa había caído de la gracia de García Moreno porque el obispo y el clero de Imbabura habían volcado el voto católico para que en las elecciones de diputados fuera electo "un ateo de profesión, un impío conocido, el fatuo coplero Julio Zaldumbide", decía García. ${ }^{42}$ Además, Checa había sido impulsado por los hermanos Gómez de la Torre para obtener el obispado de esa importante provincia del norte. Ordóñez pertenecía a una familia cuencana estrechamente vinculada con el garcianismo y fue el hombre de confianza de don Gabriel en la Iglesia. La elección es una muestra de cómo la agitación política atravesaba los muros de la catedral e involucraba al episcopado. Liberales y conservadores se trabaron entonces en un enfrentamiento frontal en el Congreso en torno a la elección del arzobispo. Tres veces debió sustanciarse la votación. En la primera ronda ambas figuras obtuvieron un empate en 21 votos, con uno solo en blanco. En una segunda instancia se produjo un fraude. Checa obtuvo 22 votos, Ordóñez 21. Cuando el Congreso iba a proclamarlo, el diputado Antonio Flores

$4 \mathrm{t}$ Ibid.

${ }^{12}$ García a Borja, Caranqui, 5 de septiembre de 1868 en Loor, Cartas, 1955, vol. 4, pp. 45-46. 
observó que se habían emitido 45 sufragios y que por lo tanto las cifras descuadraban. Intentó maniobrar para postergar la elección que no favorecería al candidato de los conservadores. Adujo que como eta día de despachar el correo y hora muy avanzada proponía postergar la elección para el lunes. Los liberales le respondieron con indignación e ironía. Le hicieron notar que después de dos rondas electorales fallidas era "sospechoso provocar una tregua" con el objeto de utilizar "medios reprobados, para conseguir la exaltación de un candidato que podía ofrecer ocasión de satisfacer mezquinas pasiones", al tiempo que se burlaron de la extensión y complejidad de su correspondencia que le impedía continuar la sesión. La moción de Flores fue denegada y se procedió a una nueva emisión de votos. Checa y Barba obtuvo la mayoría con 24 votos, Ordóñez recabó 19 y un congresista votó en blanco. De esta manera el arzobispado de la capital quedó en manos de un hombre impulsado por las tendencias liberales. ${ }^{43}$ Esta decisión fue celebrada por algunos quienes como J. A. Lozada hicieron imprimir una hoja volante para extender su Felicitación al ilustrado clero de mi patria, por la designación de Checa cuya investidura garantizaría que las "seis cruces negras ahuyentarán a esos energúmenos políticos, y esa insignia no acogerá a los Tartufos...". En la misma hoja Lozada se dolía del fallecimiento de monseñor Aguirre, el obispo de Guayaquil, y expresaba votos para que “QQuiera Dios que le suceda un sacerdote desprendido de viles miramientos humanos, y que no sea apoyo de la tiranía!" ${ }^{4}$

43. "Acta del Congreso de 11 de enero de 1868", El Nacional, 25 de enero de 1868.

${ }^{44}$ Lozada, "Felicitación", 1868 (hoja volante).
No sólo un lego festejaba la elección de Checa. También lo hizo el clero de la provincia de León, por medio de un impreso firmado por varios curas, incluso el de la matriz y el vicario de la provincia. El clero leonés expresó su regocijo porque "el sufragio de una considerable mayoría del Congreso" hubiera llamado a Checa a ocupar el cargo vacante. Los curas explicaban la alegría que los embargaba. Quito tendría un pastor solícito, sobrio y prudente, que llevaría a sus súbditos por el terreno de la verdad y la virtud "con toda paciencia y doctrina, convencido de que es más eficaz para la reforma de las costumbres la exbortación que la amenaza, más la benevolencia que la autoridad, y más la caridad que el poder". 45

Para el buen lector, los curas expresaban júbilo por la no elección de Ordóñez dispuesto a llevar adelante la reforma del clero por los métodos violentos que utilizaba su mentor, García Moreno. Espinosa garantizaba la libertad de imprenta y muchos la aprovechaban. Esas mismas garantías permitieron a la administración retomar con más calma la reforma moral del clero. Así se lo comunicó Ponce a los obispos de todas las diócesis. Les hizo saber que para la administración era una obligación y que podían contar con el apoyo completo del Estado para proceder a ella. Espinosa trataba también de distanciarse del gobierno de Carrión, donde la reforma había derrapado. ${ }^{46}$

En su última sesión el Congreso se dedicó a tomar una serie de medidas modernizantes: prohibió las corridas de toros

${ }^{45}$ Clero, "I. Sor. D. José", 1868 (hoja volante. Cursivas de la autora).

${ }^{46}$ Ponce, "Circular", El Nacional, 7 de marzo de 1868. 
y los juegos de carnaval por estar "reprobadas por la moral y la civilización", al tiempo que prohijó las representaciones dramáticas porque "mejoran las costumbres y dan vuelo a la literatura". Recomendé a los concejos municipales promover la construcción de teatros e impedir que se obstaculizaran las representaciones. Poco después el presidente sancionó los decretos legislativos y alineó su gestión con la sensibilidad moderna que se extendía en el continente. Estableció también una cátedra de obstetricia. ${ }^{47}$

Febrero se presentó muy agitado para el gobierno. Algunos atentados provinciales le generaron dificultades diplomáticas y un serio alejamiento con el grupo conservador. Los sucesos de Ambato pueden resumirse en los siguientes términos: luego de una discrepancia privada -la negativa a autorizar la boda de su hija con un joven colombiano- se produjo una disputa con Ignacio Holguín, suegro del gobernador de Tungurahua Nicolás Martínez e íntimo amigo de García Moreno. El 9 de febrero en la noche partidas de ambateños atacaron las casas y las personas de los granadinos que habitaban la capital provincial. La reacción, que fue prohijada por el gobernador en defensa de su suegro y con participación de su familia política, provocó muchos heridos y fue violenta. ${ }^{48}$ Los colombianos apelaron a su cónsul quien se encargó de hacer enérgicas reclamaciones ante el ministro Ponce.

\footnotetext{
47 "El Senado y la Cámara de Diputados reunidos en Congreso", El Nacional, 22 de febrero de 1868.

${ }^{48}$ Ignacio Holguín también cultivaba amistad con García Moreno. García a Paredes, Guachalá, 24 de mayo de 1868 en Loor, Cartas, 1955, vol. 4, p. 18.
}

A su vez Martínez acusó a los colombianos de haber reunido a sus connacionales de Latacunga y Quito para venir a Ambato a vengar la ofensa, hecho desmentido con indignación por el cónsul. El gobierno de Espinosa reaccionó enviando un piquete de tropa y separando del cargo de forma provisional al gobernador Martínez acusado de tener responsabilidad directa en la asonada anticolombiana. Lo sustituyó con el segundo candidato en la terna de las elecciones de 1865 , que era Francisco J. Montalvo, hermano de Juan, el implacable liberal crítico de García Moreno desde la prensa y el ensayo. ${ }^{49} \mathrm{E} 1$ gobierno fue también sensible a los reclamos del cónsul, quien se mostró insatisfecho con la separación provisional del gobernador porque seguía ejerciendo presión sobre los ciudadanos atemorizados con su retorno. Por ello, el 10 de marzo separó definitivamente a Martínez, encargó al gobernador Montalvo la mayor eficiencia en el tratamiento de la causa e inició la persecución donde suponían que podían esconderse, pues los familiares, haciendo uso de influencias, habían logrado huir de Ambato.

Don Gabriel trató de evitar que la provincia quedara en manos de los liberales. Desde la hacienda de Guachalá, donde pasaba su retiro, escribió a Ponce tres cartas que le pidió entregar al presidente con la esperanza de disuadirlo de esta designación pero no recibió respuesta, pese a que en la última manifestó a Ponce que "miraría el nombramiento de Montalvo como una declaratoria de

${ }^{49}$ El periódico oficial de marzo y abril está prácticamente dedicado a publicar la documentación emanada de los sucesos de Ambato. Véase El Nacional, 21 y 27 de marzo de 1868 . 
guerra" ${ }^{50}$ Se entrevistó con el ministro en Quito y aunque logró retrasar un poco el nombramiento no pudo evitarlo. Mera también presionó al gobierno. Escribió una carta a Ponce que era casi un ultimátum. Le expresaba que

\begin{abstract}
o rompe con Montalvo y el partido liberal, y nosotros [los conservadores] sostenemos el gobierno en esta provincia; o nos dice francamente que los prefiere a nosotros, y entonces no tendremos embarazo ninguno para hacer una oposición firme y tenaz. ${ }^{\text {si }}$
\end{abstract}

La designación de Montalvo en Tungurahua fue el punto final de las buenas relaciones entre el grupo conservador y la administración de Espinosa. García Moreno decía en su correspondencia: "el gobierno se ha quitado la máscara", 52 "Espinosa y Ponce se presentan como enemigos, injustos e ingratos". ${ }^{33}$ Los conservadores perdían de esta manera el control sobre una provincia en las proximidades de unas elecciones legislativas y poco después presidenciales. Sin embargo, en las de mayo triunfó el grupo conservador e incluso Martínez formó en la entidad la Sociedad Conservadora de Ambato. ${ }^{54} \mathrm{La}$ correspondencia es por demás elocuente del enojo que le produjo a don Gabriel este desliz de Martínez, al que llenó de improperios en

${ }^{50}$ García a Martínez, Guachalá, 12 de marzo de 1868 en Loor, Cartas, 1955, vol. 4, p. 8, y García a Salazar, Guachalá, 4 de mayo de 1868 en ibid., p. 14.

${ }^{51}$ Mera a García, Ambato, 22 de abril de 1868 en ibid., p. 11.

${ }^{52}$ García a Martínez, Guachalá, 27 de abril de 1868 en ibid., p. 12.

${ }^{53}$ García a Salazar, Guachalá, 4 de mayo de 1868 en ibid., p. 14.

${ }^{54}$ García a Martínez, Guachalá, 21 de mayo de 1868 en ibid., p. 17. tono más o menos amable. ${ }^{55}$ La designación de Montalvo era una inquietante demostración de que Espinosa no aceptaba ejercer el gobierno bajo tutela, que no se apartaría de la ley para favorecer a los bandos y que estaba dispuesto a actuar con energía para establecer una convivencia civilizada.

La sensibilidad política estaba a flor de piel. La simple negativa de un padre influyente a conceder la mano de su hija derivó en una batalla política y en un conflicto que hizo correr verdaderos ríos de tinta y de insultos, evidencia de una polarización exacerbada. Luego de la publicación de una "Aclaración al público" hecha por Nicolás Martínez, su sobrino Mera publicó un folleto en Defensa del Dr. NicoLás Martínez, y abundó luego en un escrito acompañado de firmas de supuestos adherentes a la Sociedad Conservadora, titulado El autor o autores de la facción marcelina en Ambato. A partir de ese momento los dos "Juanes de Ambato" (Mera y Montalvo) se batieron por el resto del año en folletos insultantes y en una escena de pugilato. Montalvo respondió con Marcelino y medio, El masonismo negro, El Búbo de Ambato y El peregrino de la Meca. Serie que remató cuando Martínez logró la absolución en el juicio y regresó a Ambato para festejar con un baile su victoria. Esta celebración coincidió con el terremoto de Imbabura y ello dio origen a una nueva diatriba de Montalvo titulada Bailar sobre las ruinas. ${ }^{56}$ Su hermano, el gobernador de

55 García a Martínez, Quito, 12 de febrero de 1868 en ibid., p. 4, y García a Martínez, La Esperanza, 10 de octubre de 1868 en ibid., p. 68.

56 Mera, Defensa, 1868; Montalvo, Masonismo, 1868. "Marcelino", "Búlo", "Bailar" y "Peregrino" pueden consultarse en Montalvo, Padre, 1997. 
Tungurahua, Francisco Javier, libró un comunicado al ministro del Interior denunciando el festejo y convocó a una plegaria colectiva de tres días sucesivos y una misa fúnebre. En su proclama a los habitantes no perdió ocasión de fustigar a sus adversarios políticos por su inoportuna celebración. ${ }^{57}$ El tema siguió ocupando durante mucho tiempo al gobierno de Espinosa, pues algunos connotados garcianos no pudieron ser apresados, y otros que lo fueron se fugaron. El gobierno debió extender orden de captura a todas las provincias. ${ }^{58}$

Aunque muy ruidosa, la separación del cargo del gobernador de Tungurahua no fue el único episodio que enfrentó al ejecutivo con los gobernadores y otras autoridades de provincia. Separó también del cargo al gobernador del Chimborazo, Bruno Dávalos. Un artículo de El Nacional, sin firma y redactado en tono de defensa del gobierno, ${ }^{59}$ respondía las acusaciones que se le hacían en Los Andes, en un artículo titulado "La vindicación del gobernador de Chimborazo". En él, y en otras hojas sueltas, se acusaba al gobierno de Espinosa de haber destituido a Dávalos "por miras eleccionarias", en alusión a la

${ }^{57}$ Montalvo, gob. de la provincia de Tungurahua, "Al H. Sr. ministro de Estado en el Despacho del Interior", 23 de agosto de 1868, El Nacional, 15 de agosto de 1868; Ponce, "Al Sr. gobernador de la provincia de Tungurahua", 26 de agosto de 1868, El Nacional; Montalvo, gobernador de la provincia de Tungurahua, "A sus habitantes", 21 de agosto de 1868 , ibid. Por error de imprenta en original se repite la fecha en dos números del periódico oficial. Por lo tanto, una serie de oficios y documentos fechados en días posteriores se publican con fecha 15 de agosto de 1868 (nota de la autora).

${ }^{58}$ Ponce, "Al señor gobernador de la provincia de...", El Nacional, 17 de junio de 1868.

59 "El Nacional", El Nacional, 2 de mayo de 1868. de senadores y diputados próximas a verificarse. El Nacional negaba esta acusación y aclaraba que la destitución se produjo porque Dávalos era un "instrumento ciego de uno de los bandos políticos que dividían Riobamba", ${ }^{60}$ por haber hostilizado al obispo Ignacio Ordóñez oponiéndose a sus obras y por haberlo ultrajado en las plazas públicas. Además, porque el gobernador perseguía a los jesuitas, expropiándoles el colegio de San Felipe Neri. También incidió en la decisión el dispendio de las rentas de la provincia y los enormes adeudos de casi un año a los empleados. El gobierno se defendía también de las críticas que recibió en la capital a través de una publicación titulada Las circulares, donde se lo acusaba de no ser "un gobierno, sino un partido en el poder" por haber omitido enviar circulares a los gobernadores provinciales encareciéndoles respetar la libertad de sufragio. El artículo explicaba que el gobierno no había deseado "meter bulla ni buscar alabanzas por su conducta", y por ello ha dirigido cartas discretas a los gobernadores recomendándoles la estricta observancia del artículo 41 de la ley de elecciones. ${ }^{61}$ La sustitución de Dávalos parece haber respondido a la necesidad de guardar equilibrios. La baja del conservador "garcista" Martínez fue seguida por la del "carrionista" Dávalos, ${ }^{, 2}$ quien fue sustituido por Carlos Zambrano, que era conservador. Cierto es que el gobierno reaccionaba con indignación extrema ante cualquier violación de la legalidad electoral. Trató de descubrir y sancionar a los violadores de las urnas del

${ }^{60} \mathrm{Ibid}$.

${ }^{61}$ Ibid.

${ }^{62}$ Dávalos era pariente indirecto de Carrión. "El Nacional", El Nacional, 2 de mayo de 1868. 
Sagrario en la parroquia central de la ciudad de Cuenca durante las elecciones legislativas, según denunciaron publicaciones conservadoras. ${ }^{63} \mathrm{El}$ enojo gubernamental se extremó cuando comprobó que en el fraude estaban involucrados los mismos encargados de hacer el escrutinio. ${ }^{64}$ La nota prometía "no tolerar la impunidad de un delito de tanta gravedad", que consistió en la suplantación de un considerable número de papeletas. Por las mismas y otras violaciones fue destituido Manuel Camba, el jefe político urbinista del cantón de Daule, provincia de Guayaquil. ${ }^{65}$ Fue sustituido por José Domingo Santiestevan, "conservador de pura sangre", como dice Borrero. ${ }^{66}$

En julio el gobierno debió enfrentar otro toque de campanas en conmemoración del primer aniversario del motín del 25 de julio del año anterior y en protesta por la voluntad reformista y continuista que sostenía Espinosa en materia religiosa. El clero rebelde, decía Ramón Aguirre, el intendente de Policía de Quito, ha convertido las campanas de la ciudad "en instrumentos propios para concitar al pueblo a la rebelión contra las leyes y las autoridades [...] en apoyo de la resistencia que se han propuesto oponer a los mandatos más santos de los prelados". Para evi-

${ }^{63}$ Ponce, "Al señor gobernador de la provincia del Azuay", El Nacional, 17 de junio de 1868, y Borrero, Refutación, 1957-1968, vol. 2, pp. 239-240.

${ }^{64}$ Ponce, "Nota al señor presidente de la Corte Superior del Azuay", El Nacional, 17 de junio de 1868.

${ }^{65}$ García, gob. de la provincia del Guayas, "Al Sr. ministro de Estado en el Despacho del Interior" [Sobre el júbilo que anima a la población del cantón por la destitución], El Nacional, 24 de octubre de 1868.

${ }^{66}$ Borrero, Refutación, 1957, vol. 2, p. 243. tar que en adelante se reiteraran estos escándalos, el intendente exhortaba a prelados y párrocos para que a la brevedad "haga poner puertas en la entrada a los campanarios y nombre uno a más personas que manejen las llaves", quienes serían responsables de los toques a rebato. ${ }^{67}$

Agosto se presentó como un mes más complicado aún. El día 3 un incendio consumió la casa y las bodegas donde se almacenaban más de 8000 quintales de cacao de Pedro Pablo García Moreno. Su hermano Miguel, el gobernador del Guayas, se mostraba convencido del carácter intencional del fuego. ${ }^{68}$ Todo parecía volverse en contra de las aspiraciones de don Gabriel. Sin embargo, los ejes políticos que impulsaba el gobierno de Espinosa se vieron trastocados. Un terremoto ocurrido en la madrugada del 15 al 16 de agosto destruyó la provincia de Imbabura, echó abajo la mayor parte de las construcciones civiles y religiosas de la capital Ibarra, de Cotacachi, Otavalo y otros puntos sensibles desde el punto de vista humano y económico. Produjo más de 20000 muertos. El temblor también se hizo sentir en Quito, donde dañó edificios históricos como las torres de la Compañía y algunos templos. ${ }^{69}$ El 17 llegaron a la capital las primeras noticias que envió el gobernador

${ }^{67}$ Aguirre, "Al venerable prelado (o párroco) de....", El Nacional, 15 de agosto de 1868.

${ }^{68}$ García, gob. de la provincia del Guayas, "Al ministro de Estado en el Despacho del Interior", $E l$ Nacional, 15 de agosto de 1868 .

69 Ponce, "Al señor gobernador de la provincia...", El Nacional, 15 de agosto de 1868. Reitero que por error se repite la fecha 15 de agosto en dos números del periódico oficial. Por lo tanto una serie de oficios y documentos fechados en días posteriores se publican con fecha 15 de agosto (nota de la autora). 
Manuel Zaldumbide, quien daba cuenta de que eran "pocos los que hemos quedado con vida". ${ }^{70}$ En los días siguientes arribaron las comunicaciones de los cantones y tenencias políticas. El jefe político de Otavalo pintaba un cuadro de desolación.

No ha quedado una sola casa parada. Los muertos son innumerables y ni se puede saber de un modo cierto cuántos son, porque se encuentran casi todos los pobladores sumergidos en los escombros [...] sin poderlos socorrer, porque los indígenas se han sublevado. ${ }^{71}$

El gobernador clamaba por el envío de fuerzas armadas para controlar el vandalaje porque "los indios y los malhechores están en absoluta mayoría sobre los pocos que han quedado".72 La ayuda del gobierno comenzó a llegar. El 22 de agosto la comisión médica enviada desde Quito a cargo del doctor Miguel Egas daba cuenta, desde Otavalo, de los muertos y sepultados del cantón, de que los pocos blancos sobrevivientes se encontraban tan turbados por su pena que sólo se ocupaban de lamentarse sobre las ruinas y el gobierno no contaba con "la cooperación de los indígenas que son los únicos que pudieran servir en esa ocasión". ${ }^{73}$ Resulta un poco difícil comprender por qué los indios no debe-

${ }^{70}$ Zaldumbide, gob. de la provincia de Tungurahua, "Al ministro del Interior", El Nacional, 17 de agosto de 1868.

${ }^{71}$ Dávila, "Al señor ministro del Interior", $E l$ Nacional, 18 de agosto de 1868 .

${ }^{72}$ Zaldumbide, gob. de la provincia de Tungurahua, "Al ministro del Interior", El Nacional, 19 de agosto, de 1868.

${ }^{73}$ Egaz, "Comisión médica, sitio en que fue Otavalo", El Nacional, 22 de agosto, 1868. rían estar ocupados en salvar a los de su "raza". Egas dejaba constancia de que entre los miles de muertos no se estaba contando a los indígenas que vivían en los contornos de la ciudad. Posiblemente esta segregación a la periferia y la precariedad de sus viviendas los hayan protegido un poco de la alta mortandad que sufrió la población blanca. Se expresaban "temores de que los indios quieran expulsarlos de sus terrenos". Tampoco puede desecharse que los blancos sobrevivientes tuvieran tan arraigados los prejuicios setranos contra el trabajo manual que aun en circunstancias extremas pensaran que remover escombros era un trabajo que sólo podía corresponder a los indios. $\mathrm{La}$ muy próspera Cotacachi prácticamente desapareció, tanto la ciudad como las haciendas y las fábricas textiles. Atuntaqui y Otavalo fueron muy dañadas e Ibarra algo menos. ${ }^{74}$

La gravedad de la situación movió al gobierno a designar un jefe civil y militar para la provincia. Espinosa colocó al frente al hombre más enérgico que tenía el país. La naturaleza le brindaba a don Gabriel una oportunidad única para reinsertarse en el escenario nacional. García asumió el cargo el 23 de agosto y se puso en marcha hacia la provincia martirizada. ${ }^{75}$ En su proclama a los habitantes de Imbabura sentó las bases de su participación: "distribuir a los buenos los auxilios" y "reprimir con penas severas a los que se han dedicado a vivir del pillaje". "¡Los malvados que tiemblen! Si continúan cometiendo

${ }^{74}$ Rivadeneira y Sierra a Ponce, "Comisión médica en Caranqui", El Nacional, 22 de agosto, 1868.

${ }^{75}$ García a Ponce, "Jefatura" en Loor, Cartas, 1955, vol. 4, p. 32. 
crímenes, serán exterminados." 76 Bajo estas premisas la actividad de salvamento, hospitales, desentierro de cuerpos, medidas profilácticas, recuperación de los caminos, reconstrucción de ciudades, pueblos, escuelas y templos fue frenética. ${ }^{77} \mathrm{~A}$ tal punto que debió alejarse unos días del encargo pues, hacia fines de octubre sufrió lo que él llamó un "ataque cerebral que no llegó a ser apoplejía”, que atribuyó a una insolación, ${ }^{78}$ y que Henderson ${ }^{79}$ supone que fue una crisis de estrés. Es posible también que la aparición, precisamente por esas fechas, de una nueva y peligrosa candidatura para las próximas presidenciales, lo hubiera alertado que había estado demasiado tiempo fuera del centro y que era aconsejable precipitar un rápido retorno. ${ }^{80}$

García se encargó de poner en orden a los curas que se habían ausentado de sus parroquias una vez producido en terremoto. Los hizo regresar a todos menos al cura de San Luis de Otavalo. Esta actitud rebelde dio lugar a que insistiera en torno a sus ideas de "religiosidad útil". Sugirió entonces al gobierno de Espinosa que tramitara ante la Santa Sede la supresión de esta parroquia porque sería: "de gran provecho para la República el sustituirlos con

${ }^{76}$ García, "A los habitantes de Imbabura", El Nacional, 15 de septiembre de 1868.

${ }^{77}$ García a Ponce, [Sobre la reconstrucción de Ibarra], La Esperanza, 14 de noviembre de 1868, en El Nacional, 28 de noviembre de 1868.

${ }^{78}$ García a Alcazar, Guachalá, 25 de octubre de 1868 en Loor, Cartas, 1955, vol. 4, p. 71

${ }^{79}$ Henderson, Gabriel, 2008, p. 141

${ }^{80}$ Los abundantes informes que envió al gobierno pueden consultarse en los dos números de El Naitonal fechados en 15 de octubre de 1868 y en el epistolario compilado por Loor, antes citado. otros de institución más reciente y más útil para la Iglesia y el Estado". 81

El terremoto no sólo fungió como la plataforma de relanzamiento electoral de su figura sino como un campo de lucha entre las tendencias políticas. El control gubernamental de las provincia seguía siendo el punto de desiderata frente a unas futuras elecciones presidenciales en las que Espinosa, casado con la legalidad, prometía estricta limpieza. Una de las primeras acciones que aplicó el jefe civil y militar fue destituir al gobernador liberal Manuel Zaldumbide pues, decía en oficio al gobierno: "La cobardía de las autoridades principales de la provincia ha aumentado los horrores causados por el terremoto." Acusó al gobernador de haber abandonado el cargo por haber ido a verificar el estado de su familia en las inmediaciones de Ibarra y dedicarse al salvamento de sus propiedades y enseres en lugar de desentertar sepultados y atender heridos. ${ }^{82} \mathrm{El}$ gobernador destituido por García Moreno era hermano del poeta Julio Zaldumbide, quien había cometido el agravio de editar el primer folleto crítico de su presidencia. La documentación muestra a un García Moreno institucional, que informaba al gobierno de la evolución de la reconstrucción. Por supuesto cometió también una importante cantidad de excesos autoritarios. ${ }^{83}$ Su designación y la obvia proyección que alcanzó su figura

${ }^{81}$ García a Ponce, "Jefatura civil y militar de la provincia de Imbabura", Caranqui, 27 de agosto de 1868, en El Nacional, 15 de septiembre de 1868.

82 García a Ponce, "Jefatura Civil y Militar de Imbabura", Caranqui, 24 de agosto de 1868 en Loor, Cartas, 1955 , vol. 4 , p. 32.

${ }^{83}$ Robalino recoge relatos de primera mano sobre estos excesos. Robalino, Orígenes, 1948, p. 382. 
abrieron una dura polémica en periódicos, folletos y hojas volantes. ${ }^{84} \mathrm{~A}$ ella contribuyó también el folleto vindicativo que hizo imprimir el ex gobernador Zaldumbide, ${ }^{85}$ en el que se defendió de las acusaciones y afirmó que fue "destituido netamente por liberal y por la incompatibilidad de las dos autoridades", 86 y no "por los informes calumniosos de García". 87 Si bien don Gabriel hizo llegar sus opiniones científicas en torno a las causas reales del terremoto, ${ }^{88}$ en su correspondencia privada le dio un tono políticamente apocalíptico, según el cual el movimiento había sido el castigo divino contra una provincia descarriada que había elegido diputado a un liberal enemigo con el apoyo del entonces obispo Checa. Consideró que ello había colmado la paciencia divina pues no podía haber "un escándalo mayor que el ver a un sucesor de los apóstoles inducir al clero $y$ al pueblo para que elijan a un enemigo

${ }^{84}$ El descontento por la designación de García se hizo sentir en la prensa. El Eco del Partido Liberal de Guayaquil publicó un artículo de Carbo que le llamó "tirano" por haber arrojado sobre la provincia arrasada la "maldición de una dictadura". "El Nacional", El Nacional, 3 de occubre de 1868. Carbo también publicó su folleto Dictadura respondido por José Modesto Espinosa bajo el pseudónimo de Cosme y Damián con una agria publicación titulada "St." Ello indignó a Montalvo quien, desde El Cosmopolita, exigió al jefe del liberalismo guayaquileño una respuesta y él mismo le dedicó agrias páginas. Montalvo a Carbo, San Juan de Dios, 26 de octubre de 1868 en Montalvo, Juan, 1960, pp. 223-224.

${ }^{85}$ Zaldumbide, "Vindicación", 1868.

${ }^{86}$ Ibid., p. 17.

${ }^{87}$ García a Ponce, "Jefatura Civil y Militar de Imbabura", Caranqui, 24 de agosto de 1868 en Loor, Cartas, 1955, vol. 4, p. 32, y García a Martínez, Caranqui, 28 de agosto de 1868 en ibid., p. 36.

${ }^{88}$ García a Ponce, "Jefatura Civil y Militar de Imbabura" en ibid., pp. 42-44. declarado de Dios, que hace gala de no creer en su existencia". ${ }^{99}$

Sobre la provincia martirizada llovió un verdadero alud de ayuda nacional e internacional. Personalidades públicas o simples ciudadanos aportaron en dinero y en insumos para reconstruirla. ${ }^{90}$ Cuando más adeptos eran al jefe civil y militar mayores eran las ayudas, como las que envió el grupo de señoras que reunió la esposa de Martínez en Ambato para fabricar ropas y calzados para evitar que las señoras ibarreñas anduvieran descalzas "caminando como las indias". ${ }^{91}$ No sólo los conservadores aportaban. Los liberales, como el gobernador Montalvo, hacían una especie de competencia solidaria. Desde el exterior también fluyó el apoyo y llegaron fondos de Perú, Chile, Francia e Inglaterra. ${ }^{92}$

Muchas otras vicisitudes sacudían al gobierno de Espinosa. En el plano hacendario el ministro Castro repartía sin éxito regaños entre los gobernadores por el no pago de sueldos y pensiones. Las autoridades provinciales argumentaban padecer una falta de recursos constante pese a que el secretario de Hacienda hacía notar la baja aplicación que ponían en incremen-

${ }^{89}$ García a Borja, Caranqui, 5 de septiembre de 1868 en ibid., pp. $45-46$.

90 "Lista de los señores que se han suscrito para proporcionar auxilios a las víctimas del terremoto acaecido el 16 de agosto de 1868", El Nacional, 15 de septiembre de 1868 .

${ }^{91}$ García a Martínez, Caranqui, 12 de septiembre de 1868 en Loor, Cartas, 1955, vol. 4, pp. 58-59.

${ }^{92}$ Comunicados varios de Antonio Flores Jijón, ministro plenipotenciario de Ecuador en Perú, El Nacional, 3 de octubre de 1868. "Comerciantes y ciudadanos de Londres, ponen en Lima crédito a disposición del gobierno", El Nacional, 22 de diciembre de 1868. 
tar la recaudación fiscal provincial. ${ }^{93}$ Aunque el gobierno gozaba, después de la firma del concordato, con $50 \%$ del diezmo, y la guerra con España había quedado atrás, la economía estaba afectada por el cambio en los circuitos comerciales $^{94}$ y por los gastos de reconstrucción. Ese mismo año se instalaba en Guayaquil un nuevo banco emisor, el del Ecuador, que tenía el compromiso de proveer un préstamo al gobierno, pero no terminaba de liberarlo. ${ }^{95}$ Excede los propósitos de este artículo el tratamiento del tema aunque hay que considerar que las tensiones fueron intensas en este plano. El arcaísmo de los mecanismos elegidos para poner en curso la nueva moneda y retirar la de circulación forzosa trababa los recursos del gobierno. ${ }^{96}$ La falta de moneda fraccional y los problemas de la conversión de los medios franceses ${ }^{97}$ incrementaron la crisis del comercio guayaquileño antes de que se introdujera moneda fraccional de cobre.

${ }^{33}$ Castro al gob. de la provincia de Los Ríos, Quito, 7 de noviembre de 1868, El Nacional, 28 de noviembre de 1868 [Sobre la baja recaudación].

${ }^{94}$ Estados Unidos, Francia, Alemania y otras naciones europeas sustituían a España en la demanda de cacao. Chiriboga, Jomaleros, 1980, pp. 44 y 363.

${ }^{95}$ En torno a la creación y funcionamiento del Banco del Ecuador, véase Estrada, Bancos, 1976.

96 El gobernador de Guayaquil y su secretario debían rubricar personalmente los billetes. Castro a García, "Oficio al señor gobernador de la provincia del Guayas, disponiendo que sin pérdida de tiempo proceda a sellar y rubricar los billetes del Banco del Ecuador", El Nacional, Quito, septiembre de 1868.

97 "Decreto ejecutivo fijando el verdadero valor de la moneda extranjera" y "Oficio del gobernador de Guayaquil contraído a dar cuenta del disgusto que ha causado en el pueblo el decreto sobre el verdadero valor de la moneda fuerte [medios franceses]", $E l$ Nacional, 12 de diciembre de 1868.
Una vez instalado el Banco y efectuado el préstamo, ${ }^{98}$ Espinosa pagó los adeudos privados y asignó fondos para continuar los caminos del Sur y de Esmeraldas. ${ }^{99}$ No sólo fue respetuoso de la ley sino también de los compromisos adquiridos.

\section{LA SUCESIÓN PRESIDENCIAL}

Hacia octubre de 1868 el clima electoral era fuerte. El segundo gobierno del Interregno se había instalado con esa amenaza sobre sí. Elecciones como sinónimo de revoluciones era un precepto matrizado entre los conservadores. Ellos, que habían sido los adalides de la ampliación del cuerpo ciudadano en la Constituyente de $1861,{ }^{100}$ sentían un temor visceral a la hora de las consultas. ${ }^{101}$ Si bien las elecciones debían verificarse en mayo de 1869 , el tema estaba sobre la mesa desde los primeros momentos de la administración. García proclamaba en su correspondencia que no volvería a gobernar un país donde "las leyes que tenemos son insuficientes para

${ }^{98}$ Despacho de Hacienda, [Contrato de empréstito al gobierno], Guayaquil, El Nacional, 11 de noviembre de 1868 y 28 de noviembre de 1868.

99 "Artículos del decreto legislativo de 21 de noviembre de 1865 que determinó la aplicación que tendría el empréstito", El Nacional, 28 de noviembre de 1868 .

${ }^{100} \mathrm{Al}$ impulsar la desaparición de las limitantes censatarias y la representación en base a la población y no a la ciudadanía expresaban su confianza infinita en "el carácter conservador" del sufragio universal y del voto "pertenencia us. soberanía", al decir de Rosanvallon, Consagración, 1999, p. 274.

${ }^{101}$ Numerosas intervenciones de diputados de esta tendencia en las constituyentes del periodo insisten en asociar las elecciones con la anarquía. Véase Buriano, Navegando, 2008, pp. 176-178. 
impedir el mal y hacer el bien”, en referencia al marco constitucional de 1861. Afirmaba que esa negativa era una manera de "sostener con más vigor los principios conservadores". ${ }^{102} \mathrm{La}$ ausencia de candidaturas generó una verdadera danza de nombres. Se mencionaba a Ponce que tendría el apoyo de los obispos. Los liberales estaban indecisos. Unos se pronunciaban por Pedro Carbo, otros por Teodoro Gómez de la Torre o Antonio Borrero y algunos por Francisco J. Aguirre.

Los conservadores estaban pendientes de la opinión de don Gabriel. Constituido en la hacienda de Guachalá y aun cumpliendo su encargo en Imbabura manejaba los hilos de la política sucesoria y nadie se animaba a sugerir una candidatura sin la aquiescencia del caudillo. García propuso la del general Darquea, con cierta lejanía. Decía que "sería leal conservador e intransigible con los rojos; pero no tengo compromiso con él". ${ }^{103} \mathrm{La}$ propuesta del jefe militar de la plaza de Guayaquil no gozó del apoyo del "partido" conservador. Así se lo hizo saber Mera al caudillo. Esta oposición provocó una malhumorada respuesta. Después de señalarle que él no aceptaría un nuevo periodo presidencial "conociendo lo absurdas que son la Constitución y las leyes que ustedes nos dieron" -en referencia a la actuación de Mera como diputado en la Constituyente de 1861 donde se plegó junto a los liberales en lo relativo al tema de las garantías individuales-, ${ }^{104}$ García hacía notar que ya había indicado al general como al mejor de los candidatos, a

${ }^{102}$ García a Salazar, Guachalá, 14 de junio de 1868 en Loor, Cartas, 1955, vol. 4, pp. 19-20.

${ }^{103}$ Ibid., p. 20.

${ }^{104}$ Véase Buriano, Navegando, 2008, pp. 197-198. "pesar de ser manco, cosa que usted tanto teme". Le decía que si el grupo conservador de Quito lo rechazaba no lo hacía por su incapacidad física, sino porque abrigaban "intereses encontrados por candidatos vergonzantes". Aislado en Guachalá don Gabriel desconfiaba de sus propios partidarios. En un hiriente símil con las monedas - de buena ley pero perforadas o de peso cabal pero mala ley- le decía a Mera que no había en Ecuador hombres públicos completos. Repasaba los candidatos posibles y los descalificaba con ironía: "manco de intenciones como Piedrahita, o tullido de alma como Ponce, o ciego por la fatuidad anticatólica como Borrero, o leprosos incurables de espíritu como los Veintimilla y todos los rojos". ${ }^{105}$

Sus correligionarios no tomaban muy en serio estas bravatas. Aun los más cercanos y fieles veían detrás de la débil candidatura del general una intención oculta: presentar un candidato tan absurdo que al final debiera ser sustituido por el propio caudillo si acaso los conservadores aspiraban a ganar la elección. Es también posible que deseara, como propone Borrero, neutralizar a Darquea para que garantizara el apoyo de "los cuarteles de Guayaquil". ${ }^{106}$ Por ello, pese a las negativas, sus partidarios insistían en ofrecerle la candidatura que él seguía rechazando. Hacia inicios de agosto, García Moreno parecía resignado a aceptar la inviabilidad de su candidato y abría una esperanza: "A pesar de mis esfuerzos la candidatura de mi amigo el Gral. Darquea ha sido rechazada aquí y contra mi expresa voluntad la

${ }^{105}$ García a Mera, Guachalá, 12 de julio de 1868 en Loor, Cartas, 1955, vol 4, pp. 23-24.

${ }^{106}$ Borreto, Refutación, 1957-1968, vol. 2, p. 127. 
Sociedad Patriótica ha lanzado la mía." Reafirmaba que no aceptaría a menos, decía, "que el pueblo me autorice a reformar (con su consentimiento) la Constitución y las leyes". ${ }^{107}$ Poco más tarde, cuando la oposición se había consolidado y relativamente unificado en torno a una candidatura rival con visos ganadores, planteó una nueva excepción a su determinación de no ejercer la presidencia una vez más. Lo haría dijo, sólo en caso de "que los rojos quisieran apoderarse del país". Esa posibilidad le parecía cercana, porque elegir a Aguirre "sería casi lo mismo que elegir a su pariente Urbina". Y, aunque amenazaba con regresar a la candidatura de Darquea, García no hablaba en serio y sus amigos lo sabían. Desde su temprana ruptura con el gobierno agitaba la idea de que se preparaba una revolución urbinista "cuyas ramificaciones se extienden a toda la República". ${ }^{108}$ A medida que la lucha electoral evolucionaba, el peligro se agigantaba en su discurso, en la correspondencia y en la prensa adicta ${ }^{109}$ y percibía

${ }^{107}$ García a Paredes, Quito, 12 de agrosto de 1868 en Loor, Cartas, 1955, vol. 4, p. 30.

${ }^{108}$ García a Borja, Quito, 8 de abril de 1868; García a Martínez, Guachalá, 2 de noviembre de 1869; García a Borja, Quito, 16 de diciembre, y García a Del Valle, Quito 23 de diciembre de 1868 en ibid., pp. 10, 74, 88, 90 y muchas más.

${ }^{109}$ García a Salazar, 1 de junio de 1868 , en ibid., p. 19. La Estrella de Panamá, tomaba de El Independiente de Valparaíso una carta llegada desde Quito donde se denunciaba un plan conjunto de los rojos José Cipriano Mosquera, José Ma. Urbina y el general Pedro Diez Canseco, presidente provisional de Perú, para invadir Ecuador y repartirlo a sur y norte. Y ello ocurría, afirmaba la carta, mientras Espinosa expedía salvoconductos a los exiliados. La Estrella de Panamá, 9 de junio de 1868. que Carrión y su ministro Ponce eran débiles. ${ }^{110}$

Las mudanzas de talante reseñadas estaban condicionadas por el juego político del momento. Ecuador vivía tiempos de relativa paz. Sectores de las elites ecuatorianas consideraban que no era necesario depender de un "salvador" cuyos excesos habían tolerado no muy a gusto durante un lustro. En todas las regiones había adeptos y oponentes. No todas las tendencias de la vida social, política y religiosa del país compartían la inspiración misional de un Estado centralizado y fundido con la religión -que había sido la tónica de la primera administración garciana. ${ }^{111}$ No la compartían los liberales de la costa que tempranamente elevaron la candidatura de Carbo; tampoco lo hacían las corrientes espiritualistas modernas que rechazaban la mixtura intensa entre lo espiritual y lo temporal que promovía García. Más bien creían que tenía una religiosidad demasiado política que escondía un deseo evidente de subordinar a la Iglesia a un proyecto gubernativo. Existían quienes, como Espinosa, deseaban impulsar la modernización católica pero en un ambiente de "reconciliación". 112 Privaba una opinión pública que no deseaba recorrer nuevamente el camino de la confrontación extrema que había abierto García. No estaban convencidos del beneficio que significaba partidizar al país. Les asustaba el rumbo que tomaba su vecina Colombia y existía un sentimiento extendido de que

${ }^{110}$ Ponce no sería buen presidente porque: "El rojo que se convierte, carece de energía para luchar contra sus antiguos compañeros." García a Toral, 22 de junio de 1868 en Loor, Cartas, 1955, vol. 4, p. 21.

${ }^{11]}$ Véase, Buriano, Navegando, 2008, p. 334.

${ }^{112}$ Henderson, Gabriel, 2008, p. 141. 
era necesario retrotraer la política a una etapa más consensual.

El más activo y coherente promotor de esta línea fue el progresismo azuayo. Los cuencanos forjaban una "forma diferente de identidad política" 113 a partir de su conflictiva relación con el garcianismo. Al comienzo habían apoyado el proyecto. Dueños de una prensa con tradición histórica, ${ }^{114}$ algunos de sus prohombres, como Mariano Cueva, llegaron a la vicepresidencia de la República durante el primer gobierno de don Gabriel. Con una participación activa en la Constituyente de 1861, promovieron las posiciones descentralistas y luego se fueron alejando del gobierno de forma gradual y no exclusivamente por los temas regionales. Desde 1863 la prensa cuencana, particularmente El Centinela y sus principales redactores Antonio Borrero y José Arízaga, expresaron discrepancias con el concordato y la política exterior de García, aunque no le retiraron plenamente su apoyo. ${ }^{15}$ Esa censura al gobierno derivó en un fraccionamiento interno, pues figuras como Benigno Malo se mantuvieron adherentes sin fisuras a la política de don Gabriel, se separaton de El Centinela y crearon La Prensa, un periódico de apoyo al régimen. De tal manera las tendencias federalistas, que tenían en Malo a su principal representante, no fueron obstáculo para que se sumara al esfuerzo que encabezó el centralismo garciano. El verdadero conflicto estalló luego de la represión, los fusila-

${ }^{113}$ Cárdenas, Región, 2005, p. 65.

${ }^{114}$ En Cuenca surgió un periodismo agresivo que tuvo sus orígenes en el padre Solano y fue continuado por los Borrero, los Malo, los Vega, los Dávila, los Arízaga y los Cordero.

115 Cárdenas, Región, 2005, pp.78-94. mientos y la campaña por la sucesión presidencial de 1865. Mientras Malo sostuvo las candidaturas "garcistas" de CaamañoCarrión, Borrero y su grupo, "los antiguos Centinelas", como los llamaba García, ${ }^{116}$ se adhirieron a la de Gómez de la Torre y. se trabaron en una agria polémica de denuncias contra la represión y las declaraciones de "insuficiencia de las leyes" que hacía el caudillo. Ello fue lo que determinó el cierre de $E l$ Centinela en mayo de 1865 , las órdenes de captura y el exilio de los redactores responsables. ${ }^{117} \mathrm{El}$ cargo diplomático que ejerció Malo durante el gobierno de Carrión y las críticas que le hizo García Moreno terminaron por romper los lazos de adhesión que los vinculaban.

¿Quién era ese grupo cuencano? Aunque con impronta regional, deseaban incidir en el plano nacional. Cárdenas los describe como un agrupamiento urbano, surgido en una ciudad profundamente tradicionalista, sin "rojos" ni caudillos, como era Cuenca. Carentes de una definición doctrinaria firme, la tensión generada por las reiteradas violaciones a la institucionalidad de la primera etapa garciana los coligó. Herederos de una tradición civilista, vinculados por lazos comerciales y de familia con los guayaquileños, educados en la Universidad de Quito y bien relacionados en la capital fueron muy apegados a la ley, a las instituciones, a la vida parlamentaria y a la discusión de ideas por medio de la prensa. ${ }^{18}$ Cultores de la función arbitral que históricamente había ejetcido el Azuay en las decisiones políti-

116 García a Borja, Guayaquil, 30 de marzo de 1867, en Loor, Cartas, 1966, vol. 3, p. 353.

${ }^{117}$ Cárdenas, Región, 2005, pp. 96-97.

${ }^{1.18}$ Cárdenas, "Construyendo", 2002-2003, p. 52. 
cas entre los dos polos principales de la República (Guayaquil y Quito) muchos aspectos del entorno, aun el económico y social, los impulsaban a ser el fiel de la balanza en el debate político. ${ }^{119} \mathrm{~A}$ lo largo de la vida republicana del país se habían manifestado dispuestos a impulsar la integración y la modernización como vía para lograr el progreso de Ecuador; sentían un marcado rechazo por la anarquía y un énfasis en el orden como marco para la libertad; eran proclives a un sistema judicial honesto basado en los juicios verbales $y$, aunque partidarios de ejecutivos fuertes, se mostraban convencidos de que sus aspiraciones podían lograrse sin golpes de fuerza. Rechazaban los "partidos", aspiraban a la conciliación, a ser la expresión del justo medio y vislumbraban en el federalismo un mecanismo para sustraer el debate del estrecho círculo de las pasiones individuales y elevarlo al amplio campo de la lucha doctrinaria y de principios. Concebían un "sistema federal de gobierno, diferente tanto del centralismo garciano como de un autonomismo radical". ${ }^{120}$ El padre Berthe los caracterizó como liberales católicos, identidad que la tendencia rechazó de manera airada, ${ }^{121}$ pues no era precisamente un galardón desde que el Syllabus la había colocado en el Catálogo de los principales errores de nuestra edad. Cárdenas prefiere sindicarlos como conservadores moderados, conservadores liberales o conservadores progresistas, los verdaderos conservadores, como se llamaban a sí mismos, influidos por el catolicismo social. ${ }^{122}$

\footnotetext{
119 Ibid., p. 53.

120 Paladines, Sentido, 1991, p. 141.

${ }^{121}$ Borrero, Refutación, 1957, vol. 2, p. 123, n. 1.

122 "El verdadero principio conservador", El Constitucional, Cuenca, 1 de diciembre de 1868 , citado en
}

Surgía así una tendencia que tuvo muchas denominaciones en su decurso pero que termino nombrándose como "progresismo".

A diferencia del liberalismo guayaquileño que había postulado a Carbo, el grupo cuencano no estaba dispuesto a arriesgar una candidatura regional. Comprendía que sólo una alianza interprovincial sería capaz de derrotar el proyecto continuista de un García bien prestigiado desde su campaña imbabureña. Entendían que el nuevo presidente no debía ser un hombre que proviniera de los grupos políticos tradicionales, sino que debería estar al margen de los partidos. Por eso, el 24 de octubre de 1868, más de 40 figuras cuencanas se dirigieron a un guayaquileño afamado, Francisco Javier Aguirre Abad, para ofrecerle la candidatura. ${ }^{123}$ Aguirre tenía perfil de estadista, concitaba la adhesión de tendencias opositoras de varias regiones y se presentaba con un programa escrito y definido. ${ }^{124}$ Era un

Cárdenas, Región, 2005, p. 105. Para la historiografía sobre la tendencia, véase ibid., pp. 68-75.

${ }^{123}$ [Carta colectiva de ciudadanos de la provincia del Azuay a Francisco Javier Aguirre], Cuenca, 24 de octubre de 1868 en Borrero, Refutación, 1957, vol. 2, pp. 135-136. Firman Benigno Malo, Antonio Borrero, Mariano Cueva, Miguel Heredia, Tomás Toral, José Joaquín Malo y siguen 38 firmas.

${ }^{124}$ Nacido en Baba, en 1808, Aguirre se doctoró en Jurisprudencia en Quito. Su ejercicio profesional se inició en el puerto, vinculado a la casa comercial de Manuel Antonio Luzárraga. Se vinculó al liberalismo y en 1852, como diputado a la Convención promovió importantes iniciativas de corte humanista, como la abolición de la pena de muerte por delitos políticos, la que privilegiaba la instrucción primaria frente a la secundaria y superior y la manumisión de esclavos. Poseía una reflexión importante sobre ese tema que plasmó en un folleto titulado 
oponente de peso y en ese año el gobierno de Espinosa le había confiado la función de interventor del Banco del Ecuador encargado de fiscalizar la conversión de los billetes, tarea que Aguirte cumplía con puntualidad. ${ }^{125}$

Cuatro días después del ofrecimiento, Borrero tomó la decisión de escribirle una difícil carta a García Moreno en la que le ofreció sumarse a la campaña a favor de Aguirte, "un término medio, un hombre distante" de los liberales y los conservadores. ${ }^{126}$ Intentó convencetlo de que, pese al parentesco con Urbina, Aguitre había sido su opositor político. Lo instó a reflexionar en torno a su propia candidatura. Le recordó sus reiteradas negativas a repetir en el mando dada la "insuficiencia de las leyes". Por ello suponía que su honor y su dignidad le impedirían jurar cum-

"Exposición al Congreso de 1854 sobre la manumisión de esclavos". Hacia 1855 representó a Ecuador en misiones diplomáticas, como encargado de Negocios en Lima y al año siguiente ejerció el mismo cargo en Chile. En estas gestiones mantuvo una decidida posición hispanoamericanista frente a las amenazas europeas. Fue firmante del primer tratado celebrado por Ecuador con la Asociación de Acreedores Extranjeros, el Aguirre-Mocatta. Hacia fines del periodo urbinista se retiró a la vida privada desde una sólida posición económica generada tanto por su origen social, como por el ejercicio de su profesión y por haber sido beneficiado con un fideicomiso de Luzárraga que le permitió adquirir una hacienda y destinar parte a obras educativas y sociales en Guayaquil. Desde los inicios del periodo garciano asesoró a Carbo en la parte jurídica de un famoso folleto contrario al Concordato. Pérez, Diccionario.

${ }^{125}$ Aguirre a Castro, "Documentos relativos a la amortización de los billetes de curso forzoso, cambiados por el Banco del Ecuador", El Nacional, 12 de diciembre de 1868.

${ }^{126}$ Borrero a García, Quito, 28 de octubre de 1868 en Borrero, Refutación, 1957, vol. 2, p. 141. plir los deberes de presidente "con arreglo a la Constitución y las leyes" como lo exigía la fórmula constitucional. Le dijo que entendía que por esta razón no aceptaría la candidatura que le ofrecían sus amigos. Aunque García respondió con una escueta nota donde no comprometió su opinión, ${ }^{127}$ no es difícil comprender que la carta de Borrero lo precipitó a tomar una decisión. De esta manera rompió el impasse político que la indefinición de las candidaturas había provocado.

Aguirte respondió a los cuencanos el 5 de noviembre con un verdadero compromiso. Adelantó su aceptación. Se mostró escéptico de lograr la "fusión" de los partidos que le sugetían los cuencanos pues "en otros países más adelantados las pruebas que se han hecho no han sido realmente satisfactorias". Reconoció en su carta que "En todas las naciones, la división de partidos es un hecho constante, necesario y a veces útil", pero no en Ecuador, donde el hombre más digno y de virtud más acendrada de todos los que ocuparon la presidencia de la República -en referencia a Espinosa- fue aceptado por todos los partidos pero los mismos que lo llevaron al puesto lo hostilizaron. Por ello, argumentaba Aguirre, "No debemos hacernos ilusiones esperando que se unan los partidos", sino separarlos y alejarlos del gabinete y de los empleos superiores y apelar a "hombres nuevos", porque además ello contribuiría a que se aplicara el principio constitucional de la alteridad necesaria en los empleos de gobierno. Se tipificaba a sí mismo como un "hombre independiente" que requería ministros y agentes "de su propia escuela". Concluyó

127 García a Borrero, Guachalá, 8 de noviembre de 1868 en Loor, Cartas, 1955, vol. 4, p. 78. 
señalando que era conveniente "realizar una especie de tregua, que dé lugar a que se apacigüen los odios, y se busque en la legalidad, el triunfo de los partidos". ${ }^{128}$ El guayaquileño había superado la visión de los "partidos" como expresión de la demagogia. No veía el unanimismo fusionista como una virtud. Entendía que la existencia de grupos de opinión alineados en torno a institutos políticos diferenciados no sólo era legal sino legítima pero también que Ecuador no tenía aún el clima necesario para alcanzar ese logro modernizador. El planteo tendía un lazo hacia aquellos sectores del liberalismo que poseían una definición doctrinaria. Aguirre pugnaba por el voto guayaquileño consolidado en tomo al liderazgo de Carbo.

Poco debe haber contribuido a la recuperación de la salud de García Moreno la noticia de que el candidato de los cuencanos aceptaba postularse. Antes de conocerlo y desde su reposo en Guachalá decía sentirse casi seguro de la "negativa del Dr. Aguirre por sus enfermedades y por su invariable repugnancia a salir a la Sierra". Pensaba entonces que el grupo terminaría candidateando a Malo. Estaba convencido que los conservadores obtendrían la mayoría. Afirmaba que "Ni Aguirre, ni Malo tendrán los votos que turo Manuel Gómez de la Torre"129 porque "el horizonte de Cuenca no es el de la República; y la fusión de allá no influirá gran cosa fuera de aquel cantón". ${ }^{130}$ García creía que sólo su sector

${ }^{128}$ Aguirre a Malo, Cuenca, 5 de noviembre de 1868, en Borrero, Refutación, 1957, vol. 2, p. 137.

${ }^{129}$ García a NN, Guachalá, 8 de noviembre de 1868 en Loor, Cartas, 1955, vol. 4, pp. 77-78.

${ }^{130}$ García a Borja, Guachalá, 28 de noviembre de 1868 en ibid., p. 85 (las cursivas aparecen en negritas en original). era capaz de visualizar al horizonte de la nación. En esta apreciación parecía olvidar que él mismo, con su convocatoria a la Constituyente de 1861, había dado un golpe de gracia a la representación regional al abolir con intención de integración nacional la representación igualitaria de los tres departamentos. ${ }^{131}$ Con ello había contribuido a la ampliación de la mirada política nacional.

Reponerse de su enfermedad y retomar la jefatura civil y militar de Tungurahua consumió las fuerzas del caudillo durante el resto del mes de noviembre. Quizá por ello su correspondencia es escasa. Pero la vida política del país no le daba reposo. La campaña avanzaba y ocupaba a la prensa. El 20 de noviembre apareció en Cuenca un nuevo periódico bajo el sugerente nombre de El Constitucional, editado por Borrero y con la colaboración de los prohombres del grupo: Malo, Cueva, Arízaga y Cordero. En su efímera vida, sólo seis números entre la fecha de su nacimiento y el 10 de enero de 1869 , fue el órgano de la campaña electoral de Aguirre. El Correo del Ecuador, bajo la dirección de Pablo Herrera, sería, junto a otros ( $L a$ Patria, La Estrella de Mayo, El Joven Conservador) el firme sostén de las propuestas garcianas. El Cosmopolita, de Montalvo, reapareció en noviembre de 1868 en cinco números con una serie de escritos titulados "El nuevo Junius", ${ }^{132}$ y el Eco del Partido Liberal aportó también para mantener agitada a la opinión pública.

${ }^{131}$ Véase Buriano, Navegando, 2008, pp. 157-162.

${ }^{132}$ El último artículo de la serie de "El nuevo Junius" se publicó en el último número de El Cosmopolita del 15 de enero de 1869 bajo el título de "A la clase militar", véase Montalvo, Páginas, 1993, pp. 30-35. 
Benigno Malo se encargó de presentar la candidatura de Aguirre en el primer número de El Constitucional, invitando a la unión para restaurar la dignidad del país de forma pacífica, para lograr la prosperidad de la Hacienda pública, el comercio y la agricultura, para respetar a la Iglesia en sus derechos y libertades, para garantizar la libertad de todos los sectores sociales y formas de pensamiento, para vivir un gobierno que no obraría sino "dentro de sus atribuciones legales". ${ }^{133}$ En el mismo número los progresistas azuayos insistían en negar la existencia de corrientes de pensamiento verdaderamente diferenciadas en Ecuador, donde liberales y conservadores no eran más que "nombres recientemente importados de la vecina Colombia, pero sin [...] verdadera significación entre nosotros" decían. ${ }^{134}$

Pese a esta opinión, los clubes y sociedades electorales se extendían. Las sociedades conservadoras tenían presencia desde el fin del primer gobierno de García, en Quito por lo menos. Ahora sus incondicionales las fundaban en las provincias. En mayo de 1868 nacía la Sociedad Conservadora de Ambato, creada por Martínez y Mera. ${ }^{135}$ La Sociedad del Progreso del Azuay, aunque formalmente constituida el 2 de enero de $1869,{ }^{136}$ se denominaba

${ }^{133}$ Malo, "La candidatura para la presidencia de la República en el próximo periodo constitucional", El Constitucional, 20 de noviembre de 1868 en Borrero, Refutación, 1957, vol. 2, pp. 144-148.

134 "Programa", El Constitucional, 20 de noviembre de 1868 en ibid., p. 132

135 "Ha hecho Ud. bien en formar la Sociedad Conservadora. Seamos unidos y los rojos se verán... reducidos a la impotencia." García a Martínez, Guachalá, 21 de mayo de 1868 en Loor, Cartas, 1955 , vol. 4 , p. 17.

${ }^{136}$ Cárdenas, "Construyendo", 2002-2003, p. 66. como tal desde fines de octubre e inicios de noviembre y, con lo más selecto de las personalidades públicas de la provincia, lanzaba la postulación de Aguirre. La Sociedad Republicana de Quito la apoyó inmediatamente con una "Manifestación" suscrita por importantes personalidades políticas, por algunos integrantes de la Corte Suprema, por escritores y literatos y varios canónigos. ${ }^{137} \mathrm{La}$ Sociedad Conservadora del Azuay no se quedó atrás. Con el patrocinio de varias figuras proclamó a García. Finalmente, el 28 de noviembre la Sociedad Patriótica de Quito, después de dejar constancia de que había consultado con las sociedades de todas las provincias, sostuvo a García Moreno como su candidato. ${ }^{138}$

Actos insólitos sucedían, por lo menos en el Azuay. Borrero dio cuenta de una "procesión" con cirios en la mano dando vivas a Francisco Javier Aguirre. El padre Berthe los acusó de gritar mueras a García Moreno, al concordato, al papa y al clero, hecho que Borrero negó enfáticamente, aunque reconoció que grupos conservadores se les enfrentaron dando gritos contra Benigno Malo. ${ }^{139}$ No existieron ni existirían, hasta fines de siglo y en pleno curso de la revolución liberal, este tipo de expresiones públicas callejeras, indicio innegable de la polarización que adquirió la contienda electoral impulsada por las sociedades. Aguirre se perfilaba como el candidato capaz de conjuntar los múltiples descontentos provinciales. Aunque Carbo no aceptó unírseles, no debe olvidarse que Aguirre era un guayaquileño

137 "Manifestación", en Borrero, Refutación, 1957, vol. 2, pp. 139-141.

${ }^{138}$ Ibid., p. 128.

${ }^{139}$ Ibid., pp. 193-194. 
muy poderoso y enraizado en la sociedad costeña, capaz de arrastrar tras su figura el voto mayoritario.

Por otra parte, la contienda se sustanciaba entre programas escritos. Las propuestas programáticas de Aguirre que difundía El Constitucional se basaban en la observación de la Constitución y las leyes, la independencia de las municipalidades y la modificación de la ley de división territorial, la abolición de los impuestos a la sal y los alimentos, el pleno saneamiento monetario, el pago puntual de las deudas privadas del Estado, el respeto a la Iglesia y a las garantías individuales. ${ }^{140}$ García no podía seguir quedando rezagado frente a lo que llamaba "el partido de la fusión", ni era admisible que mantuviera el coqueteo de la indefinición. Por ello, en carta a la Sociedad Conservadora del Azuay aceptó la candidatura a mediados de diciembre y esbozó su contraprograma. Justificó entonces las circunstancias que lo obligaron, contra su voluntad, a asumir un nuevo compromiso: la presentación de la candidatura de Aguirre lo indujo porque, decía: "pariente, aliado y favorecedor de Urvina, anuncia claramente que [...] si fuera elegido sería el precursor necesario de un traidor para quien en esta República no puede haber más lugar que el cadalso". Sumó a esta antipolítica presentación otros agravios. Dijo que los católicos progresistas azuayos se sumaban a la candidatura de Aguirre porque "son enemigos del concordato, se burlan del Sumo Pontífice y del Syllabus y regalan el apodo jansenítico de ultramontanos a los verdaderos hijos de la Iglesia". Esbozó entonces los lineamientos programáticos de su nuevo go-

${ }^{140}$ Campos, "Galería biográfica de hombres célebres ecuatorianos", citado en ibid., p. 152. bierno: respeto y protección a la religión católica, adhesión a la Santa Sede, fomento de la educación basada en la moral y la fe, difusión de la enseñanza en todos los ramos, conclusión y apertura de nuevas obras públicas, garantías a las personas y las propiedades, fomento del comercio, la agricultura y la industria, libertad para todo y todos menos para el crimen, represión a la demagogia y la anarquía y buenas relaciones con los vecinos y otras potencias: "un país moral y libre, civilizado y rico". ${ }^{41}$

Los actores estaban en la escena y los programas sobre la mesa. En sus últimos números, El Constitucional lanzó sus baterías para demoler la candidatura de García. Un artículo de Mariano Cueva criticó el programa garciano. ${ }^{142}$ Lo comparó reiteradamente con Napoleón III e Iturbide por fraguar falsos pretextos para coartar las libertades y construir enemigos para deshacerse de aquellos que deseaban aniquilar. Vaticinó que no cumpliría la promesa jurada de respetar la Constitución. Puso en duda su religiosidad y concluyó su artículo afirmando: "el señor García Moreno es hombre temible, es un tirano". Este juicio fue reafirmado nuevamente en El Constitucional por una reflexión de Benigno Malo titulada "Las dos escuelas", ${ }^{143}$ en la que comparaba al islamismo con el cristianismo garciano y afirmaba que en Turquía se respetaban las libertades más que en Ecuador, y que Abdul-

${ }^{141}$ García a Borja, Quito, 16 de diciembre de 1868 en Loor, Cartas, 1955, vol. 4, pp. 88-90.

${ }^{142}$ Cueva, "Programa del señor García Moreno", El Constitucional, s. n. en Borrero, Refutación, 1957, vol. 2, pp. 173-184.

${ }^{143}$ Malo, "Las dos escuelas", El Constitucional, 10 de enero de 1869 en ibid., pp. 184-191. 
Azzis era preferible a García Moreno. Afirmó que en el país había dos escuelas políticas, la constitucional y la dictatorial. La constitucional tenía por lema: "La libertad en el orden es la fuerza [...] fuerza moral que hace a las naciones invencibles." La agresividad del periodismo progresista cuencano era extrema, por ello García instaba a sus partidarios en Cuenca a contrarrestar la campaña fundando un periódico partidario para el que ofrecía una contribución personal de 50 pesos mensuales para financiarlo. ${ }^{144}$

\section{EI DESENLACE DE LA COYUNTURA: REFLEXIONES SOBRE LA POLÍTICA}

La correspondencia de García Moreno indica que se mantuvo entre la hacienda de Guachalá y La Esperanza, el nuevo emplazamiento de la ciudad de Ibarra, hasta el 28 de noviembre de 1868. El 16 de diciembre, cuando aceptó la candidatura, ya estaba instalado en Quito. Los garcianos pasaron unas navidades intranquilas. Habían perdido toda esperanza de modificar "la neutralidad equivocada"145 y el legalismo civilista de Espinosa, a quien acusaban de "tener simpatías antiguas por Aguirre" y ser hierático "como un ídolo del paganismo", ${ }^{146}$ indiferente frente a las denuncias de los conservadores sobre una supuesta invasión urbanista en la costa. ${ }^{147}$ Sostenía que Urbina había

${ }^{144}$ García a Borja, Quito, 23 de diciembre de 1868 en Loor, Cartas, 1955, vol. 4, p. 92.

${ }^{145}$ Ibid.

146 García a Toral, Quito, 23 de diciembre de 1868 en ibid., p. 93.

${ }^{147}$ Antonio Borrero transcribe al padre Berthe quien señala la publicación de un folleto donde se llegado a Tumbes con sus generales Ríos y Franco en espera de que la revolución estallara en Guayaquil después de haber asesinado a Darquea, y que en el resto de las provincias se hacía acopio de armas. ${ }^{148}$ Eran noticias falsas. García Moreno y sus seguidores no podían ignorarlo. El verdadero temor de los conservadores era la posible victoria de la coalición interprovincial que había elevado a Aguirre.

Por ello no dudaron en desestabilizar al gobierno de Espinosa. Contaron con la alianza del ministro del Interior, Camilo Ponce, y de José Modesto Espinosa, hermano del presidente. Javier Espinosa descubrió la conjura y exigió la renuncia a su infiel primer ministro. Los garcianos se concentraron en Quito a principios de año. En la madrugada del 16 de enero García Moreno lideró un cuartelazo unánimemente respaldado por la guarnición de la capital y el mismo día viajó a Guayaquil. La plaza estaba asegurada por su fiel general Darquea. Todo el ejército era garcista, dice Borrero. ${ }^{1 / 9}$ Una junta de notables quiteños, presidida por Rafael Carvajal, emitió un acta de pronunciamiento que intentó dar algún viso de legalidad al golpe de Estado. El acta subrayaba que el presidente Espinosa prohijaba, con su debilidad y tolerancia, a connotados urbinistas y enemigos del orden situados en cargos de gobierno. Sostenía que Urbina se hallaba en la frontera esperando que se le entregara la plaza para lograr "el imperio de las doctrinas llamadas liberales y por consiguiente el aniquilamiento completo de los principios religiosos, morales

publicaban cartas relativas a un complor de los insurgentes. Borrero, Refutación, 1957, vol. 2, p. 224.

${ }^{148}$ Ibid., p. 223.

149 Ibid., pp. 239-240, 
y políticos en los que estriban la estabilidad y progreso de las naciones." Por esas razones los notables cesaban al presidente de la República y situaban, en condición de presidente interino, a García Moreno y en la vicepresidencia, también interina, a su cuñado Manuel Ascásubi. Preveían la convocatoria a una convención nacional que reformaría la Constitución. ${ }^{150}$ En una proclama, García Moreno prometía

ante Dios y ante el pueblo, por mi palabra de honor jamás violada, que una vez asegurado el orden y reformadas las instituciones, me separaré del mando y lo entregaré al que sea designado por la libre voluntad del pueblo, sin aceptarlo para mi aunque fuere elegido. ${ }^{151}$

El golpe de Estado no enfrentó resistencia. La oposición se escondió o exilió, como lo hizo Montalvo. Fue un violento corte que sesgó una coyuntura promisoria, un "hasta aquî" al tiempo de la política entendida como debate de posiciones y de ideas. Aunque no plenamente formulado, el programa garciano había quedado inconcluso en las concesiones que debió realizar para afianzarse en el poder. El proyecto y su principal figura maduraron en medio de los embates que sufrieron durante el Interregno, cuando fueron oposición. Se vieron obligados a plasmar un esbozo de programa escrito de gobierno. Se confrontaron con opositores de alto nivel político que tenían también una propuesta de alcance nacional. Todo el edifi-

150 "Acta de pronunciamiento, Quito, 16 de enero de 1868" en Loor, Cartas, 1955, vol. 4, pp. 96-98.

151 "Gabriel García Moreno, a sus conciudadanos", Quito, 17 de enero de 1868 en Borrero, Refutación, 1957, vol. 2, p. 252. cio construido durante su primer lustro se tambaleaba. Se alejaba la idea del Ecuador católico, moderno, progresista, fundado en la fe y aliado con el papado. Sabían que la violación de las instituciones los obligaba a dejar por el camino no sólo la legalidad sino el apoyo de amplios sectores de las elites, que sus alianzas se estrechaban. Se separaban de esa mixtura de fuerzas inicial que los había arropado y constreñido a un tiempo. Perdían el consenso que los había llevado al poder en 1861, pero entendían que ya no podían avanzar con todo ese espectro disímil en la obtención de los objetivos máximos que plasmarían finalmente en la Constitución de 1869. No sólo los garcianos habían madurado. La oposición también lo había hecho amparada en la libertad de imprenta del Interregno. Tenía un programa definido, una proyección y un liderazgo transregional. Era agresiva y pugnaba por la opinión pública desde la prensa. El debate político había dado un salto y se modificaba demasiado rápido. Aunque el término "partidos" era muy usual, predominaba en todos los bandos el rechazo a legitimarlos, ${ }^{152}$ aunque los grupos de opi-

${ }^{152}$ Pese a que el espectro político no era incipiente, las elites ecuatorianas y muchas latinoamericanas se aferraban a no legitimar la existencia de partidos. Asociaban la partidización con el caos, la anarquía y la "demagogia". Guerra y Palti han estudiado este fenómeno. El primero lo asoció al organicismo del antiguo régimen. Palti, por el contrario, lo alejó de su conexión con un pasado retardatario y lo adscribió a un momento moderno de la opinión pública, ligado con la racionalidad del liberalismo clásico que exigía la discusión de un problema concreto al margen del origen político de quien proponía la solución. De esta manera un "partido" era legítimo si se formaba exclusiva y espontáneamente para resolver un problema, pero no lo era si se constituía 


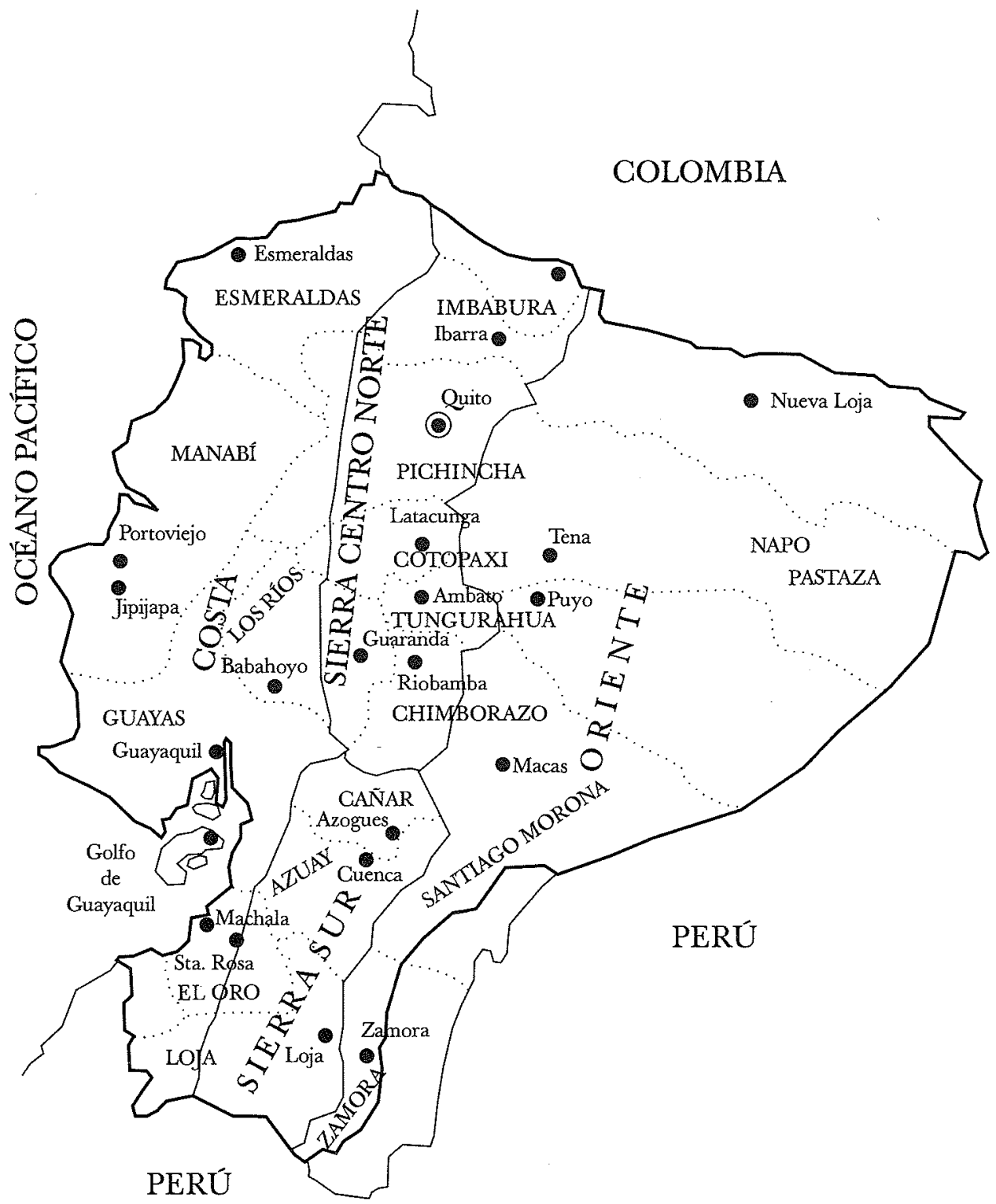


nión se asumían bajo las identidades políticas de conservadores, liberales y progresistas. Pero la coyuntura electoral de 1868 , que prometía ser pulcra, había activado de tal manera la discrepancia que amenazaba con descomponer el "campo semántico" del debate político socialmente aceptado hasta entonces. Este se manejaba aún dentro de los marcos de algunas verdades socialmente aceptadas: para liberales y progresistas giraba en torno al respeto a la institucionalidad legal y constitucionalmente establecida. Los garcistas ponían el énfasis en la fe que, por otra parte, no negaban sus oponentes. ${ }^{153}$ Aún era posible concebir el pacto, como el que propuso Antonio Borrero a García Moreno en aras de lograr la paz para la organización nacional. Pero ese acuerdo relativamente posible se erosionaba muy rápido. La prensa, particularmente El Constitucional, era el principal actor de esta descomposición. $Y$ no sólo ella; abundaban las hojas volantes y hasta las manifestaciones callejeras. Todos estos medios pugnaban por ganar la opinión pública para su proyecto. El debate se convertía en un verdadero campo de batalla "estratégico" que minaba consensos. ${ }^{154}$

Esa dinámica transicional fue abortada por el golpe de Estado de enero de 1869.

como una posición fija, irracional y antimoderna. Las facciones se concebían como "partidos sabáticos" que actúan en el momento electoral pero luego se retraian. Véase Palti, Tiempo, 2007, p. 175, n. 27. Esta y otras críticas generaron un debate historiográfico sustanciado en Aguilar, "Tiempo", 2008 y la respuesta de Palti, "Pecado", 2008. Para el tema del rechazo a los partidos puede consultarse también Rojas, Mecánica, 2006, pp. 20-24.

${ }^{153}$ Era ese momento "jurídico" o "forense" al que apela la búsqueda explicativa de Palti. Palti, Tiempo, 2007, pp. 169-178.

154 Ibid., pp. 192-198.
Entonces los conservadores garcianos pudieron desarrollar su proyecto a plenitud. Lograron detener el tiempo de la política para activar lo político, para priorizar el poder, la construcción del Estado y la nación. ${ }^{155}$ El desenlace de la coyuntura impidió la aplicación del proyecto alternativo esbozado por el progresismo. Sin embargo, el pensamiento de la oposición cuencana en sus vertientes civilista, constitucionalista y tercerista llegaría de manera efímera al poder luego del asesinato de García Moreno y, modificada, trascendería en un proyecto que se impuso en las décadas finales del siglo.

La confrontación de ideas quedó atrás. El futuro sería de realizaciones bajo un proyecto que no tuvo enfrente una oposición articulada. Este corto tiempo de la política nos permitió observar cómo se comportaron los distintos actores en la luchan por el poder y cómo esa propia lucha los fue reconfigurando. Asistimos al momento germinal en que una elite regional amplía su horizonte, concibe la nación, elije fuera de sus estrechas fronteras la figura capaz de generar alianzas y formalizar un programa. Con su activismo, sus sociedades, su prensa y su proselitismo obligaron a que sus contrarios concretaran su propio proyecto, el que ya habían esbozado y que ahora amenazaba con escurrirse de sus manos. La política transcurría entre personalidades: García, Aguirre, Carbo, Borrero, Malo y muchos otros. Más allá de que pocos deseaban ser asociado a un "partido", todos se reconocían dentro de ciertas identidades: había conservadores y "verdaderos conservadores", había liberales moderados, porque

${ }^{155}$ Rosanvallon, Historia, 2003 , p. 20, citado en Rojas, Mecánica, 2006, p. 28. 
los radicales conspiran desde fuera del país, y surgían los "progresistas". El espectro estaba diferenciado pero había "una imposibilidad mental de aceptar la institucionalización de la división", como señala Rojas para el caso mexicano, y esta imposibilidad atravesaba todo el espectro político, se presentaba como una especie de "cosmovisión" generacional. ${ }^{156} \mathrm{~A}$ falta de partidos los clubes y sociedades ocuparon la escena. ${ }^{157}$ Aunque las fuentes manejadas no autorizan un estudio de estas asociaciones a las que la corriente de la historia política ha dado amplia consideración, ${ }^{158}$ sabemos que se nuclearon en torno a las logias, las sociedades de beneficencia, las literarias y las cofradías. ${ }^{159}$ En ellas participaron elencos civiles y eclesiásticos y, como en otros casos latinoamericanos, fueron un gran campo de activación de la política, de ampliación de la participación y contribución a la ciudadanización. Aunque sospechamos que los nuevos sectores incorporados por esta vía no lograron evadir plenamente las redes de dependencia personal en ámbitos regionales, no puede desconocerse que actua-

${ }^{156}$ Rojas, Mecánica, 2006, p. 20.

${ }^{157} \mathrm{El}$ asociacionismo posindependiente tuvo larga trayectoria en Ecuador dedicado a la activación del debate político. Las más notorias sociedades políticas nacieron con la oposición a Juan José Flores. Nos referimos a la Sociedad del Quiteño Libre, la Filotécnica y otras.

${ }^{158}$ Han tenido un amplio y documentado tratamiento en obras como la de Sábato, Ciudadanía, 1999 , pp. 22-24 y varios capítulos sobre distintos paises.

${ }^{159}$ En el periodo estudiado la cofradía del Rosario, que funcionaba en el Convento de Santo Domingo, dirigida por seculares, agrupaba a fervientes opositores a García Moreno. Véase Buriano, Navegando, 2008, pp. 250-251. ron también como agrupamientos en pos de programas políticos. Su papel en el proceso electoral parece haber sido destacado hasta el punto de suscribir programas, seleccionar candidatos y organizar actos proselitistas. A estas sociedades se les debe una mejor consideración que la aquí lograda en la valoración de la coyuntura. El auge del asociacionismo confluye además con una participación incrementada del electorado luego de las reformas de 1861. . $^{160}$

No pasa inadvertida la importancia que las tendencias dieron a los cargos gubernativos provinciales en la coyuntura electoral. La más o menos equilibrada política de destitución y sustitución de gobernadores y otras autoridades que practicó Espinosa dio lugar a declaratorias de guerra al gobierno. El control regional que los gobernadores y jefes políticos ejercían sobre los procesos electorales era reconocido, y el fraude, denunciado por las tendencias derrotadas pero practicado por todas, no parece ser el desiderátum de la legitimidad del futuro gobierno. La centralidad estaba ocupada por el acto electoral en sí, y la novedad del momento fue la tozuda voluntad de Espinosa de castigar y dejar atrás las prácticas fraudulentas. Como la reciente bibliografía ha demostrado, incluso el fraude convergía al objetivo de extender la participación y la movilización del electorado. En tanto que práctica sistemática de unos y otros, el equilibrio necesario residía más en el adecuado reparto del control provin-

${ }^{160}$ Como resultado de estas reformas se constata un incremento de la participación, aunque muy bajo en relación a la población: $3.3 \%$ en 1865 , mientras que en 1830 participaban apenas $0.3 \%$. Véase Maiguashca, "Proceso", 1994, p. 399. 
cial que en la pureza del acto electoral en sí. ${ }^{161}$

La agitación política permeó al episcopado, que dividió sus preferencias y fue un activo promotor de las tendencias: el arzobispo Checa y el obispo Ordóñez muestran los extremos. El clero se expresaba con prudencia pero de manera bastante clara. En un país pequeño pero con grandes dificultades de comunicación, la vida política transcurría entre toques de campanas a rebato y "procesiones" con cirios, en la prensa, en los clubes y sociedades y entre amigos que intercambiaban correspondencia. Esta última exhibe un particular tono de hacer política, donde el encargo de las buenas botas que se fabrican en Ambato se mezclaba con la definición de las candidaturas gubernativas y legislativas nacionales y regionales; donde las intervenciones para salvar de la justicia a algún amigo exaltado transcurrían entre redes de amistosa adhesión y se mezclaban con las enfermedades y los pésames por las pérdidas familiares. Esta mixtura de sociabilidad personal y política que el epistolario analizado revela debetía ser interrogada con mucho más cuidado del que permiten los límites y propósitos de este artículo, tanto en cuanto al alcance de las redes y jerarquías de relaciones como en su formulación discursiva. Quede su mención como un campo de posibles abordajes a la historia política del Interregno.

El electoralismo de 1868 , en su nueva modalidad, se presenta como un parte aguas, un momento excepcional e irrepe-

${ }^{161}$ En torno al papel del fraude electoral en el proceso de ciudadanización véase Irurozqui, Bala, 2000; Palti, Tiempo, 2007, pp. 193-196, y Malamud, Legitimidad, 2000, pp. 8-10. tible de la vida política de Ecuador que por su potencial frustrado merece una mayor atención de la historiografía. A ello, con muchas insuficiencias y pendientes, pretende contribuir este estudio.

\section{FUENTES CONSULTADAS}

\section{Hemerografía}

El Nacional, enero de 1866-diciembre de 1868. La Estrella de Panamá, 9 de junio de 1868.

\section{Folletos, hojas volantes y epistolario}

-Caamaño, José María "Exposición relativa a la circular del excmo. Sr. presidente de la República Dr. G. García Moreno, fechada en Quito, febrero de 1865 " en Wilfredo Loor (comp.), Cartas de Garía Moreno, Ecuatoriana, 2a. ed., Quito, 1966, vol. 3, pp. 291-292.

-El Clero de la Provincia de León, "El I. Sor. D. José Ignacio Checa", Latacungua, Imprenta del Colegio por M. Hurtado, 24 de enero de 1868 (hoja volante).

-Ecuador, Cámara de Senadores, Acta del Senado. Exclusión del doctor Gabriel García Moreno del Senado del Ecuador en la sesión del 24 de agosto de 1867, Oficina Tipográfica de F. Bermeo, por Julián Mora, Quico, 1867.

-Espinosa, José Modesto, [Cosme y Damián], Al Sor don Pedro Carbo presunto candidato de unos liberales de Guayaquil, Imprenta Nacional por M. Mosquera, Quito, 1868.

-Galindo, Pío David, La reforma religiosa en el Ecuador, Oficina Tipográfica de F. Bermeo, Quito, 1866.

-García Moreno, Gabriel, "A Juan que volvió tullido de sus viajes sentimentales"; "Soneto bilingüe dedicado al Cosmopollino" en Manuel María Pólit Laso (comp.), Escritos y discursos: 
Gabriel García Moreno, Imprenta del Clero, Quito, 1887, vol. 1, pp. 296-297.

-Loor, Wilfredo (comp.), Cartas de García Moreno, Ecuatoriana, Quito, 2a. ed., vol. 3, 1966; La Prensa Católica, Quito, vol. 4, 1955.

-Lozada, J. A., Felicitación al ilustrado clero de mi patria, Imprenta Nacional, Quito, por $M$. Mosquera, 6 de julio de 1868 (hoja volante).

-Mera, Juan León, Defensa del Dr. Nicolás Martínez, Imprenta Nacional por Mariano Mosquera, Quito, 1868.

-Montalvo, Juan, Masonismo negro, Imprenta Nacional por Mariano Mosquera, Quito, 1868. , "Carta al señor Carbo, San Juan de Dios, 26 de octubre de 1868" en Juan Montalvo, estudio y selección por Gonzalo Zaldumbide, Cajica, Puebla, 1960, pp. 223-224.

-Ponce, Camilo, El 25 de julio de 1867, Imprenta de Manuel Rivadeneira, Quito, 1867.

-Unos quiteños, El señor $G$. García Moreno y don Julio Zaldumbide, Imprenta Nacional por $\mathrm{M}$. Mosquera, Quito, 1865.

- La verdad demostrada a los detractores de la comunidad dominicana del Ecuador, Oficina tipográfica de F. Bermeo por J. Mora, 1867.

-Zaldumbide, Julio, El Congreso, don Gabriel García Moreno y la República, Oficina Tipográfica de F. Bermeo, Quito, 1865.

-Zaldumbide, Manuel Ignacio, Vindicación del ex gobernador de la provincia de Imbabura, Oficina Tipográfica de F. Bermeo, Quito, 1868

\section{Bibliografía}

-Aguilar, José Antonio, "El tiempo de la teoría: la fuga hacia los lenguajes políticos", Istor. Revista de Historia Internacional, núm. 35, 2008, pp. 129-136.

-Berthe, Agustín, García Moreno: presidente de la República del Ecuador, vengador y mártir del derecbo cristiano, Víctor Retaux, París, 1892.
-Borrero, Antonio, Refutación del libro del Rvdo. padre A. Bertbe titulado García Moreno, presidente del Ecuador, vengador y mártir del derecho cristiano, Casa de la Cultura Ecuatoriana/Núcleo del Azuay, 2a. ed., Cuenca, Ecuador, 1957-1968, 3 vols.

-Buriano, Ana, "El constitucionalismo conservador ecuatoriano: un instrumento en la construcción de la hegemonía", Signos bistóricos, núm. 11, enero-junio de 2004, pp. 64-95.

, Navegando en la borrasca: construir la nación de la fe en el mundo de la impiedad, Ecuador, 1860-1875, Instituto Mora, México, 2008.

-Cárdenas, Ma. Cristina, "Construyendo el Estado nacional desde la región: el progresismo azuayo del siglo XIX", Procesos: Revista Ecuatoriana de Historia, núm. 19, 2002-2003, Quito, UASB, pp. 49-74.

, Región y Estado nacional en el Ecuador: el progresismo azuayo del siglo XIX, 1840-1895, Academia Nacional de Historia/Universidad Pablo Olavide, Quito 2005.

- Catálogo de los principales errores de nuestra edad, que ban sido censurados en las alocuciones consistoriales, en las encíclicas i otras letras apostólicas de nuestro santísimo padre Pío IX, Imprenta y Encuadernación de Calvo y CA, Guayaquil, 1865.

-Chiriboga, Manuel, Jornaleros y gran propietarios en 135 años de exportación cacaotera, 1790 1925, Consejo Provincial de Pichincha, Quito, 1980 .

-Estrada, Julio, Los bancos del siglo XIX, Casa de la Cultura Ecuatoriana/Núcleo del Guayas, Guayaquil, 1976.

-Gouhir, José Le, Un gran americano: García Moreno, 1821-1921, La Prensa Católica, Quito, 1923.

-Henderson, Peter, Gabriel García Moreno and Conservative State Formation in the Andes, University of Texas Press, Austin, 2008.

, "La constitución ecuatoriana de 1861: el debate", Procesos: Revista Ecuatoriana de Historia, núm. 30, 2009, Quito, UASB, pp. 47-67. 
-Irurozqui, Martha, A bala, piedra y palo: la construcción de la ciudadanía política en Bolivia, 1826-1852, Diputación de Sevilla, Sevilla, 2000.

- Jijón, Jacinto, Política conservadora, Banco Central del Ecuador/Corporación Editora $\mathrm{Na}$ cional, Quito, s. a.

-Maiguashca, Juan, "El proceso de integración nacional en el Ecuador: el rol del poder central, 1830-1895" en J. Maiguashca (ed.), Historia y región en el Ecuador, 1830-1930, Corporación Editora Nacional/FLACSO/CERLAC, Quito, 1994, pp. 355-420.

-Malamud, Carlos (coord.), Legitimidad, representación y alternancia en España y América Latina: Las reformas electorales, 1880-1930, FCE/COLMEX, México, 2000.

-Montalvo, Juan, "Carta al señor Carbo, San Juan de Dios, 26 de octubre de 1868" en Juan Montalvo, estudio y selección por Gonzalo Zaldumbide, Cajica, Puebla, 1960, pp. 223-224.

Páginas escogidas, Biblioteca Ayacucho, Caracas, 1993. , El Padre Lachaise. El antropófago, Pío XII/Ediciones Casa de Montalvo, 3a. ed., Ambato, 1997, t. 1.

-Paladines, Carlos, Sentido y trayectoria del pensamiento ecuatoriano, CCyDEL-UNAM, México, 1991.
-Palti, Elías José, El tiempo de la política: el siglo XIX reconsiderado, FCE-Argentina, Buenos Aires, 2007.

"El pecado de la teoría: una respuesta a José Antonio Aguilar", Istor. Revista de Historia Internacional, núm. 35, 2008, pp. 137-154.

-Pérez, Rodolfo, Diccionario biográfico Ecuador, $<$ http://www.diccionariobiograficoecuador.com> [Consulta: 10 de agosto de 2011.]

-Robalino, Luis, Orígenes del Ecuador de boy: Garcia Moreno, Talleres Gráficos Nacionales, Quito, 1948.

-Rojas, Beatriz (coord.), Mecánica política: para una relectura del siglo XIX mexicano. Antología de correspondencia política, Instituto Mora, México, 2006.

-Rosanvallon, Pierre, La consagración del ciudadano: bistoria del sufragio universal en Francia, Instituto Mora, México, 1999.

Por una bistoria conceptual de lo politico, FCE, Buenos Aires, 2003.

-Sábato, Hilda (coord.), Ciudadanía politica y formación de las naciones: perspectivas bistóricas de América Latina, FCE/COLMEX, México, 1999. 